\title{
Tulane
}

\author{
Tulane Economics Working Paper Series
}

\section{Financial Constraints and Firm Tax Evasion}

\author{
James Alm \\ Tulane University \\ jalm@tulane.edu
}

\author{
Yongzheng Liu \\ Renmin University of China Renmin University of China \\ yongzheng.liu@ruc.edu.cn \\ zkwjmd@ruc.edu.cn \\ Working Paper 1901 \\ April 2019
}

\begin{abstract}
Most analyses of tax evasion examine individual behavior, not firm behavior, given obvious and recognized data issues. We use data from the Business Environment and Enterprise Performance Survey to examine tax evasion at the firm level, focusing on a novel determinant of firm tax evasion: the financial constraints (or credit constraints) faced by the firm. Our empirical results indicate across a range of alternative specifications that more financially constrained firms are more likely to be involved in tax evasion activities, largely because evasion helps them deal with financing issues created by financial and credit constraints. We further show that the effects of financial constraints are heterogeneous across firm ownership, firm age, and firm size. Lastly, we present some suggestive evidence on the possible channels through which the impact of financial constraints on firm tax evasion may operate, including a reduction of information disclosure through the banking system, an increase in the use of cash for transactions, and an increase in bribe activities in exchange for tax evasion opportunities.
\end{abstract}

Keywords: Tax evasion; financial constraints; firm-level data. JEL codes: E26; G2; H26. 


\title{
Financial Constraints and Firm Tax Evasion ${ }^{1}$
}

\author{
James Alm \\ Department of Economics \\ Tulane University \\ Email: jalm@tulane.edu \\ Yongzheng Liu \\ School of Finance \\ China Financial Policy Research Center \\ Renmin University of China \\ E-mail: yongzheng.liu@ ruc.edu.cn
}

\author{
Kewei Zhang \\ School of Finance \\ Renmin University of China \\ $\&$ \\ Department of Economics \\ Boston University \\ E-mail: zkwjmd@ @ruc.edu.cn
}

\begin{abstract}
Most analyses of tax evasion examine individual behavior, not firm behavior, given obvious and recognized data issues. We use data from the Business Environment and Enterprise Performance Survey to examine tax evasion at the firm level, focusing on a novel determinant of firm tax evasion: the financial constraints (or credit constraints) faced by the firm. Our empirical results indicate across a range of alternative specifications that more financially constrained firms are more likely to be involved in tax evasion activities, largely because evasion helps them deal with financing issues created by financial and credit constraints. We further show that the effects of financial constraints are heterogeneous across firm ownership, firm age, and firm size. Lastly, we present some suggestive evidence on the possible channels through which the impact of financial constraints on firm tax evasion may operate, including a reduction of information disclosure through the banking system, an increase in the use of cash for transactions, and an increase in bribe activities in exchange for tax evasion opportunities.
\end{abstract}

Keywords: Tax evasion; financial constraints; firm-level data.

JEL Classifications: E26; G2; H26.

1 We would like to thank Janina Enachescu and other participants at the $5^{\text {th }}$ International Conference on "The Shadow Economy, Tax Evasion and Informal Labor", held in Warsaw, Poland in July 2017, for many helpful comments. This research was supported by the National Natural Science Foundation of China (No. 71773128; No.71533006) and the Fok Ying Tung Education Foundation (No.151085). We are especially grateful to two anonymous referees for many helpful comments and suggestions that have substantially improved the paper. 


\section{$\underline{\text { 1. Introduction }}$}

There is little question that tax evasion plagues many countries. "Tax evasion" refers to illegal and intentional actions taken by agents to reduce their legally due tax obligations. Most often these actions are viewed through the lens of individuals via the individual income tax, and in fact most theoretical and empirical work on tax evasion has focused on the individual income tax. Individuals can evade income taxes by underreporting incomes; by overstating deductions, exemptions, or credits; by failing to file appropriate tax returns; or even by engaging in barter to avoid taxes. However, these types of actions can clearly be taken in other taxes. For example, in the corporate income tax, firms can underreport income, overstate deductions, or fail to file tax returns, just as individuals do in the individual income tax. Similarly, indirect taxes like the value-added tax (VAT) present numerous opportunities for evasion. However, with some exceptions (Wang and Conant, 1988; Crocker and Slemrod, 2005; Goerke and Runkel, 2006), the basic Allingham and Sandmo (1972) model used in nearly all theoretical analyses of tax evasion has focused on the individual, and not the firm.

Likewise, most empirical work has also largely examined individual evasion of the individual income tax, again with some exceptions (Rice, 1992; Murray, 1995; Alm, Blackwell, and McKee, 2004). This is now starting to change, given recent empirical work on firm evasion by Uslaner (2010), Pomeranz (2015), Best et al. (2015), Alm, Martinez-Vazquez, and McClellan (2016), and Carillo, Pomeranz, and Singhal (2017), as well as an important recent study by Beck, Lin, and Ma (2014). Even so, the determinants of firm tax evasion remain $\operatorname{murky}^{2}$

2 See Cowell (1990), Andreoni, Erard, and Feinstein (1998), Slemrod and Yitzhaki (2002), Sandmo (2005, 
In this paper we examine firm tax evasion, focusing on one main research question:

Do the financial constraints faced by a firm increase the extent of firm tax evasion? We argue that financial constraints are likely to matter for firm tax evasion, for two reasons. First, financial constraints prevent a firm from gaining full access to external finance, which may in turn force the firm to resort to tax evasion to generate revenues internally. In perfect capital markets, a firm is in theory indifferent between internal and external funds to finance its investment and other activities (Modigliani and Miller, 1958). However, with capital market imperfections, it is either too difficult or too expensive for a financially constrained firm to obtain external finance, which forces the firm to rely more fully upon internal funds. These internal funds may come from the firm's core operations, and they may also come from the firm's attempt to reduce its explicit tax liability via tax evasion (Mayberry, 2012). Thus, tax evasion may be a means by which a financially constrained firm generates internal funds to finance its various activities. ${ }^{3}$

Second, financial constraints faced by a firm are, to a large extent, reflective of underdeveloped financial markets in the economy, and the absence of developed financial markets creates incentives for the firm to operate in the informal (rather than the formal and legal) sector. In an economy with underdeveloped financial markets, a firm may be able to circumvent tax obligations and other official rules by operating in the informal sector. Of course, operating in the informal sector comes at the cost of sacrificing all benefits of

2012), and Alm (2012, 2018) for comprehensive surveys and assessments of the tax evasion literature. See especially Slemrod and Weber (2012) for a discussion of the challenges of empirical work.

3 In related work, Baumann and Friehe (2010) show theoretically that tax evasion increases a firm's future expected profits, making more investment feasible. In empirical work, Edwards, Schwab, and Shevlin (2016) provide evidence that firms treat tax planning strategy as a source of financing. Of special relevance, they find evidence that firms facing financial constraints will take actions to increase internally generated funds via tax planning strategies that help reduced the firms' tax payments. 
operating in the formal sector (Blackburn, Bose, and Capasso, 2012). However, these benefits are reduced in an economy with underdeveloped financial markets, because credit is both less available and more costly in the presence of underdeveloped financial markets (Johnson et al., 2000). ${ }^{4}$ Indeed, in a theoretical model of tax evasion and bank intermediation, Blackburn, Bose, and Capasso (2012) demonstrate that the marginal net benefit of income disclosure decreases when the level of financial development in the economy falls, and Beck, Lin, and Ma (2014) find supporting empirical evidence that firms in countries with poorer credit information-sharing systems and lower branch penetration evade taxes to a greater degree.

On balance, then, we hypothesize that a firm that faces a higher level of financial market constraints will respond by increasing its tax evasion activities. It is this hypothesis that we examine empirically.

Using detailed firm-level data gathered by the World Bank over multiple countries and years in its Business Environment and Enterprise Performance Survey (BEEPS), we employ both ordinary least squares (OLS) and instrumental variable (IV) methods to answer our main research question. We find across a range of alternative specifications strong evidence that more financially constrained firms are more likely to be involved in tax evasion activities, largely because evasion helps them deal with financing issues created by financial market constraints. These results also show that the effects of financial constraints are heterogeneous across firm ownership, firm size, and firm age. We also find suggestive evidence that financial market constraints operate by reducing information disclosure through the banking

\footnotetext{
${ }^{4}$ Recent work on financial markets argues that the development of financial markets leads to improved credit availability and lower transaction costs of credit. For example, see Brown, Jappelli, and Pagano (2009). 
system, by increasing the use of cash for transactions, and by increasing bribe activities in exchange for tax evasion opportunities.

Our paper contributes to the literature in three ways. First, we provide empirical evidence for the recent theoretical discussion on the potential linkage between financial development and firm tax evasion (Straub, 2005; Quintin, 2008; Blackburn, Bose, and Capasso, 2012). Despite these recent theoretical developments, there is still little evidence that thoroughly examines how financial development, particularly credit constraints faced by the firms, affects tax evasion decisions at the micro level. A notable and important recent exception here is Beck, Lin, and Ma (2014), who investigate how firms make evasion decisions in response to different levels of external financial sector outreach. However, their work focuses more on the macro impacts of financial development on firm tax evasion, namely better credit information-sharing systems and higher branch penetration among banks in a country. In contrast, our work examines the impact of credit constraints at the micro, or firm, level, thereby providing more direct and more explicit evidence for the relationship between financial development and firm tax evasion. Second, as previously noted, most existing empirical work on tax evasion has focused on the individual, not the firm. We are therefore able to contribute to the small but growing literature on the determinants of firm tax evasion by exploring the role of financial constraints. Third, we provide suggestive evidence on the potential channels through which the impact of financial market constraints on firm tax evasion may operate, which may serve as a good starting point for further endeavors in this regard.

The rest of the paper is organized as follows. Section 2 describes data and variables. 
Section 3 discusses our empirical strategy. Section 4 presents our empirical results, including

OLS and IV estimation results, various robustness checks, tests for heterogeneous effects

(e.g., differential effects by firm ownership, size, age, and sector), and analysis of some possible channels. Section 5 concludes.

\section{Data and Variables}

\subsection{Data}

We use data largely from the 2002 and 2005 Business Environment and Enterprise Performance Survey (BEEPS), which is a firm-level survey of a representative sample of an economy's private sector that covers a broad range of business environment topics including access to finance, corruption, infrastructure, crime, competition, and performance measures. ${ }^{5}$ The survey includes roughly 6,500 firms in 2002 and 9,500 firms in 2005 from 27 transitional countries. ${ }^{6}$ In order to ensure the representativeness of the sample, the BEEPS employs a stratified random sampling method, with all population units are grouped within homogeneous groups and simple random samples are selected within each group. ${ }^{7}$

Additionally, the BEEPS ensures that at least 10 percent of the total sample in each country should be in the small (2-49 employees), 10 percent in the medium (50-249 employees) and

\footnotetext{
5 Although the World Bank Enterprise Survey (WBES) provides an even larger dataset in terms of country coverage (i.e., 102 countries) and year coverage (i.e., 2002-2010), there were changes in the questionnaires across years, making some of the key variables unavailable for our empirical analysis, particularly the instrumental variables for financial constraints faced by the firms. For this reason, we rely on the BEEPS for our main empirical estimations, using the WBES dataset for robustness checks but without addressing the endogeneity concern of the financial constraints faced by the firms.

6 These countries includes Albania, Armenia, Azerbaijan, Belarus, Bosnia and Herzegovina, Bulgaria, Croatia, Czech Republic, Estonia, FYR Macedonia, Georgia, Hungary, Kazakhstan, Kyrgyz Republic, Latvia, Lithuania, Moldova, Poland, Romania, Russia, Serbia, Slovak Republic, Slovenia, Tajikistan, Turkey, Ukraine, and Uzbekistan.

7 The strata for BEEPS are firm size, sector, and geographic region within a country.
} 
10 percent in the large (250-9,999 employees) size categories, and at least 10 percent of the

firms should be from small cities or the countryside. The sectoral composition (i.e.,

manufacturing versus services industries) of the total sample is determined by the relative

contribution to GDP, subject to a minimum of 15 percent of the total sample for each sector. ${ }^{8}$

Thus, the BEEPS enables us to explore not only cross-country diversity but also

within-country variation across firms of different sizes, ownership, and sectoral

characteristics.

\subsection{Key Variables}

\subsubsection{Measuring Tax Evasion}

The tax evasion variable, denoted as Percent Reported Sales, is constructed using

responses from a survey question in the BEEPS asking each firm about the amount that the

"typical" firm in its area reports for tax purposes as a percentage of sales. ${ }^{9}$ Hence, a larger

value for Percent Reported Sales indicates that the survey respondent believes that the typical

firm is less involved in tax evasion activities. Asking a firm directly about its own reporting

decision is of course likely to result in unreliable responses, as respondents are often wary of

incriminating themselves and/or they may wish to present themselves in a positive light

(Elffers, Weigel, and Lessing, 1987). Indirect survey questions seek to limit this misreporting

by asking about the behavior of others. The respondent's answer is assumed to be informed by

\footnotetext{
${ }^{8}$ Firms that operated in sectors subjecting to government price regulations and prudential supervision, such as banking, electric power, rail transport, and water and wastewater, were excluded.

9 The full question text is: "Recognizing the difficulties many firms face in fully complying with taxes and regulations, what percentage of total annual sales would you estimate the typical firm in your area of business reports for tax purposes?" The survey instrument does not provide guidance on a firm's "area of business", and this can be construed by respondents in a number of ways, such as geographic area, industry area, or perhaps even both. As a result, we have included additional fixed effect controls at the geographic (location), country, and industry levels in our specification in which we clustered standard errors at country level. See Section 3.1.
} 
its own experiences, and the World Bank emphasizes to firms that any firm responses to these questions will lead to no legal repercussions. Further, the questions are framed in a way that a firm's "sensitive behavior" is somehow justified, by the use of "forgiving wording". The firm's answer is thus assumed to be a reasonable proxy for the firm's own behavior. Because of this, the self-assessment approach has been widely employed by business surveys such as BEEPS and World Bank Enterprise Surveys in studying the illicit behavior of firms, including firm tax evasion behavior, as applied in several recent studies of firm tax evasion (Beck, Lin, and Ma, 2014; Alm, Martinez-Vazquez, and McClellan, 2016). However, while the indirect nature of the survey questions mitigates misreporting due to self-presentation reasons, answers to the questions may still be subject to misreporting due to a firm's misperceptions of its own behavior. Further, as shown by Kundt, Misch, and Nerré (2017), these survey data are likely to underestimate the true extent of firm tax evasion because a firm may be reluctant to answer truthfully questions about sensitive issues like tax evasion. ${ }^{10}$ However, the lack of formal high-quality audit data often makes these types of survey data the only way to investigate tax evasion at the microeconomic level. Also, as suggested by the results of Kundt, Misch, and Nerré (2017), our estimation results may only capture the lower bound of the impact of financial constraints on tax evasion, given that the survey data are likely to underestimate firm evasion.

The same indirect approach is also used to measure other evasion variables (Percent

\footnotetext{
10 By protecting the privacy of respondents through bundling of sensitive questions about illicit behavior of the firms and about "harmless" topics, Kundt, Misch, and Nerré (2017) develop a new survey method (the "crosswise" model) to provide more credible estimates about the extent of tax evasion. However, their approach does not allow them to generate data that could be used to examine the determinants of tax evasion at the firm level.
} 
Reported Workforce, Percent Reported Wage Bill), which we use as alternative measures of tax evasion in our robustness checks. ${ }^{11}$ Table A1 in the Online Appendix reports the average values for Percent Reported Sales across countries in our sample. It also presents information on heterogeneity using data on the means and standard deviations by countries for the average proportion of firms engaging in evasion. The Percent Reported Sales ranges from an average of 70.5 percent in FYR Macedonia to more than 95 percent in Estonia, with an average of 85.6 percent across countries. The variation in Percent Reported Sales is large both across and within countries, with a cross-country standard deviation of 11.9 percent and a within-country standard deviation of 20.9 percent. $^{12}$

One view of firm evasion is that such evasion varies mainly at the country level and not at the firm level. However, as demonstrated in Table A1, the high within-country variation in Percent Reported Sales suggests that the firm's evasion decisions are not determined solely by country characteristics. The use of firm-level data in cross-country work on tax evasion has become increasingly important, and its use has several decisive advantages over the use of aggregate country-level data (Johnson et al., 2000; Beck, Demirguc-Kunt, and Maksimovic, 2005).

\subsubsection{Measuring Financial Constraints}

In addition to basic information on firm characteristics and behaviors toward taxation affairs, the BEEPS also collects information on self-reported measures of financial

\footnotetext{
11 Just as with Percent Reported Sales, Percent Reported Workforce and Percent Reported Wage Bill represent a firm's percent workforce and wage bill reported for tax purpose. See Section 4.4.1 for a detailed definition.

12 The cross-country standard deviation is calculated from country average values, whereas the within-country standard deviation is calculated as the mean of the within-country deviations of firm tax evasion across countries.
} 
constraints faced by the firms. Specifically, we construct two financial constraints variables from responses to the following two questions: how problematic is access to financing (e.g., collateral required or financing not available from banks) for the operation and growth of your business; and how problematic is cost of financing (e.g., interest rates and charges) for the operation and growth of your business. The responses to these questions range from a scale of 1 ("No obstacle") to a scale of 4 ("Major obstacle"). ${ }^{13}$ We denote the resulting financial constraints variables as Difficulty of Access to External Finance and Cost of External Finance, respectively. ${ }^{14}$

As with self-reported measures of tax evasion, self-reported measures of financial constraints are prone to potential measurement errors and may be distorted by subjective or cultural biases, especially when the interviewers are from the public sector or a financial institution. Nevertheless, we argue that these issues should not be a major concern here, since neither government officials nor financial institutions are involved in the collection of the survey data. To further reduce the concern of the measurement errors, we provide an additional check on the linkage between the self-reported financial constraints and the more objective cross-country differences in financial development. Figure A1 in the Online Appendix plots the aggregated average score of financial constraints of the firms against two standard country-level indicators of financial development, or the ratio of private credit to GDP and the ratio of bank assets to GDP, across countries and over years. Our two measures

13 All responses include "No obstacle =1", "Minor obstacle =2", "Moderate obstacle = 3", "Major obstacle = 4". The ordinal nature of the response variable allows the variable to be used as an independent variable to measure the severity of obstacles to business operation.

14 This same measure of financial constraints faced by the firms is also employed by Gorodnichenko and Schnitzer (2013). 
of financial constraints, Difficulty of Access to External Finance and Cost of External Finance,

are strongly and negatively correlated with macro indicators of financial development,

indicating that high development in financial sector in a country is associated with low

financial constraints faced by the firms. Our measures of financial constraints are thus

meaningful indicators of financial development, and they do not seem prone to suffer from

subjective and/or cultural biases.

\subsection{Other Variables}

\subsubsection{Instrumental Variables}

As we discuss in the next section, we employ instrumental variable (IV) estimation

methods to address the potential endogeneity of financial constraints. While the rationales for the selection of the instruments, along with the relevant validity tests, are explicitly laid out in the next sections, we provide here the definitions of the five selected instruments, including:

Overdue, Share of Non-conventional Payments, Lost Sales, and two country-level indicators

for the speed of the European Bank for Reconstruction and Development (EBRD) reform in both the banking sector and non-bank financial institutions. More specifically, Overdue is a dummy variable equal to 1 if a firm currently has overdue payments and 0 otherwise. ${ }^{15}$ Share of Non-conventional Payments is the share of a firm's payments settled by debt swaps or offsets and exchange of goods for goods. ${ }^{16}$ Lost Sales is the percent of lost in terms of total sales that were due to unanticipated events. ${ }^{17}$ Finally, the two country-level indicators for the

15 Overdue is constructed from answers to the question: "Do you currently have any payments overdue (by more than 90 days) to each of the following (utilities, taxes, employees, material input suppliers)?"

16 Share of Non-conventional Payments is constructed from answers to the question: "What share of your purchases from suppliers (sales to your customers) was ultimately settled by: Debt swaps or offsets; Exchange of goods for goods?"

17 The construction of Lost Sales is based on several questions because different questions are asked in different 
speed of the European Bank for Reconstruction and Development (EBRD) reforms are based

on EBRD specific classification system about the country-specific progress in banking and

non-banking financial sectors. ${ }^{18}$

\subsubsection{Other Control Variables}

We control for an array of firm-level factors that may affect the tax reporting decision

of the firms. One factor is whether the firm has been previously audited by external auditor

(Audited). This variable controls for the audit probabilities faced by the firm, and also

potentially controls for other omitted variables that are correlated with both financial

environment and audit activities. Audited is determined from the survey question that asks if

the firm was audited by an external auditor, and it equals 1 if the firm was audited and 0

countries and across different waves of the BEEPS. In the 2002 survey, the variable is constructed from responses to the question: "What percent of sales in 2001 was lost due to delivery delays from your material input suppliers?" In the 2005 survey, the variable is constructed from the responses to the following two questions: "What percent of total sales was lost due to the following service interruptions: Power outages or surges from the public grid; Insufficient water supply; Unavailable mainline telephone service?" and "What percent of the value of products your establishment shipped over the last 12 months was lost while in transit due to breakage, spoilage or theft?"

18 The scores for the speed of the EBRD reforms are based on different classification systems. For speed of reform in banking sector, we use the following classification: 1: Little progress beyond establishment of a two-tier system. 2: Significant liberalization of interest rates and credit allocation; limited use of directed credit or interest rate ceilings. 3: Substantial progress in establishment of bank solvency and of a framework for prudential supervision and regulation; full interest rate liberalization with little preferential access to cheap refinancing; significant lending to private enterprises and significant presence of private banks. 4: Significant movement of banking laws and regulations towards BIS standards; well-functioning banking competition and effective prudential supervision; significant term lending to private enterprises; substantial financial deepening. 4+: Standards and performance norms of advanced industrial economies; full convergence of banking laws and regulations with BIS standards; provision of full set of competitive banking services. For speed of reform in non-bank financial institutions, we use the following classification: 1: Little progress. 2: Formation of securities exchanges, market-makers and brokers; some trading in government paper and/or securities; rudimentary legal and regulatory framework for the issuance and trading of securities. 3: Substantial issuance of securities by private enterprises; establishment of independent share registries, secure clearance and settlement procedures, and some protection of minority shareholders; emergence of non-bank financial institutions (for example, investment funds, private insurance and pension funds, leasing companies) and associated regulatory framework. 4: Securities laws and regulations approaching IOSCO standards; substantial market liquidity and capitalization; well-functioning non-bank financial institutions and effective regulation. 4+: Standards and performance norms of advanced industrial economies; full convergence of securities laws and regulations with IOSCO standards; fully developed non-bank intermediation. "+" and "-" ratings are treated by adding 0.33 and subtracting 0.33 from the full value. Averages are obtained by rounding down; for example, a score of 2.6 is treated as $2+$, but a score of 2.8 is treated as 3-. For more information, see:

http://www.ebrd.com/cs/Satellite?c=Content\&cid=1395237866249\&d=\&pagename=EBRD\%2FContent $\% 2 F C o$ ntentLayout. 
otherwise. The costs of tax evasion are proxied by survey questions that ask the firm's view of tax administration being an obstacle to doing business (Tax Administration as Obstacle) and its view of tax rates as an obstacle (Tax Rates as Obstacle). These variables are assessed by asking the survey respondent to what degree each factor (tax administration or tax rates) is an obstacle to the firm's current operations, with four responses ranging from "No obstacle" (or 1) to "Major obstacle" (or 4). ${ }^{19}$ Additional factors that may affect the firm's evasion decision are various firm-specific variables, such as the age of the firm $(\ln (A g e))$, the number of its employees $(\ln ($ Labor $))$, and its total sales $(\ln ($ Sales $))$, which are included as separate variables. We include several variables that measure the specific location of the firm, such as whether it is located in the capital city of the country (Capital) or the size of the city in which it is located (Other, Over 1,000,000; Other, 250,000-1,000,000; Other, 50,000-250,000; Under 50,000). Finally, in the robustness checks in subsection 4.4.2, we also include other firm-specific features as control variables, including a dummy variable for whether the firm competes in national markets (Competition), whether the firm is a member of a business association (Association), the number of establishments (ln(Establishments)), and Manager's Time Spent with Officials.

In addition to the firm-level control variables, we include some factors at the country level. First, a country's population (In(Population $))$ and its income (ln(Real GDP per Capita) $)$ are included to control for the scale effects of economic and financial development. Second, Corporate Income Tax Rate is added to capture an alternative explanation of tax evasion at

19 As before, the possible responses range from "No obstacle =1", "Minor obstacle = 2", "Moderate obstacle = 3", "Major obstacle = 4", and include a "Don't know" response. 
the country level. Lastly, we include two indicators, Bank Concentration and Bank Cost to Income Ratio, which control for the depth and the efficiency in financial sectors. In robustness checks, the Stock Capitalization Ratio (or the ratio of stock market capitalization to GDP), the Bank Loan Ratio (or the ratio of bank credit to bank deposits), the Boone Indicator, and the Lerner Index are included, which increase our confidence that the two indicators of financial constraints employed do not capture the effects of other dimensions of financial development.

The descriptions and the summary statistics for all variables are presented in Table 1.

The summary statistics demonstrate substantial heterogeneity in both individual firm characteristics and in country features.

\section{$\underline{\text { 3. Empirical Strategy }}$}

\subsection{Econometric Specification}

To assess empirically how financial constraints affect a firm's evasion decision, we employ the following econometric specification:

$$
\begin{aligned}
\text { Percent Reported Sales }_{i s c t}= & \alpha+\beta \text { Financial Constraint } \text { Csct }+X_{i s c t} \gamma+C_{c t} \delta \\
& +\theta_{c}+\lambda_{s}+\mu_{t}+\varepsilon_{i s c t}
\end{aligned}
$$

where Percent Reported Sales is our measure of the extent of firm evasion; Financial Constraint represents the two indicators of financial constraints facing the firm (i.e., Difficulty of Access to External Finance and Cost of External Finance); $X$ contains various firm-specific characteristics; and $C$ is a vector of country-level control variables, as discussed above. The specification also includes country $\left(\theta_{c}\right)$ and industry $\left(\lambda_{s}\right)$ dummy variables to control for 
unobserved heterogeneity that are constant over time across countries and industries, as well as a year dummy variable $\left(\mu_{t}\right)$ to control for year effects that affect all countries and al industries. $\varepsilon_{i s c t}$ is an idiosyncratic error term.

\subsection{Instrumental Variable Method}

A potential concern is that the endogeneity of financial constraints may bias the OLS estimates in our baseline specification (1). In our particular context, the issue may arise because of reverse causality, measurement errors, and omitted variable bias. First, it is conceivable that a high level of firm tax evasion may imply that the firm has less information being shared with the formal banking system, which in turn induces a higher entry cost for firms to access the bank credit market and so a deterioration in firms' access to external finance. ${ }^{20}$ Second, even though we have shown that the self-reported measures of firm financial constraints are largely consistent with financial development measured at country level, measurement errors may still exist due to firms' misperception of their own financial situation and the inherent difficulty of measuring financial constraints. Third, due to data limitations, not all relevant factors in explaining firm tax evasion can be explicitly included in the econometric specification (e.g., measures of the penalty rate), and these omitted variables might be correlated with financial constraints. Thus, the endogeneity of financial constraints may also be caused by the potential omitted variable bias.

To circumvent the endogeneity issue and to identify the causal impact of financial constraints on firm tax evasion, we use instrumental variable estimation. We follow

${ }^{20}$ For example, banks may require a larger value of collateral for bank loan applications, or they may increase the interest rates of bank loans for those firms with little information disclosed or few credit records. 
Gorodnichenko and Schnitzer (2013) by employing five instrumental variables, as discussed earlier: whether firms have overdue payments (Overdue); the Share of Non-conventional Payments (e.g., debt swaps, offsets, or barters); Lost Sales due to events beyond the firm's control; and two country-level indicators for the speed of the European Bank for Reconstruction and Development (EBRD) reform in both the banking sector and non-bank financial institutions. The first three instruments vary across firms and years, capturing the exogenous shocks to a firm's cash flow. Such shocks affect the amount of internal funds and the attractiveness of firms to external creditors, but they should not influence a firm's tax evasion decision directly. In particular, Overdue and the Share of Non-conventional Payments act as effective indicators for a firm's financial condition in the short run, as shown in Table 2. When a firm is exposed to a 10 percent hypothetical and unexpected loss of cash flow, about 45 percent of the firms choose to have payments overdue to suppliers, while another 29 percent (21 percent) of the firms delay payments to workers (budgetary and extra-budgetary funds), and 25 percent of the firms resort to exchange of goods for goods (i.e., barter) to deal with the financial situation. Hence, both Overdue and Share of Non-conventional Payments appear to be strong predictors of a firm's cash flow, and so of a firm's financial constraints. Also, Lost Sales reflects losses of firms due to exogenous and unanticipated events, which seem likely to be beyond the firm's control and so exogenous to a firm's tax evasion decision. Lost Sales also seem likely to be a good predictor for the firm's current liquidity and thus a good instrument for financial constraints faced by the firm.

The last two instruments are at the country level, where a higher speed of reforms in either the banking or the non-bank financial sector is associated with a lower level of 
financial constraints faced by the firms in that country. However, it seems unlikely that the speed of reforms will directly affect the firm's tax evasion decision. ${ }^{21}$

\section{Empirical Results}

\subsection{Descriptive Evidence}

We first present some descriptive evidence to show the potential linkage between the financial constraints faced by the firms and their tax evasion decisions. Figure 1 depicts the general correlation between average scores of financial constraints and firm tax evasion across countries. The strong negative correlation in Figure 1 suggests that firms tend to under-report sales for tax purpose when facing more severe financial constraints. Similarly, Table A1 in the Online Appendix presents suggestive evidence that financial constraints appear to be one of the determinants of firms' evasion decision. For example, Estonia has an average score of difficulty of access to external finance (cost of external finance) around 1.780 (1.857), and its level of Percent Reported Sales exceeds 95 percent. In contrast, in a country with relatively severe financial constraints like Serbia, the percent of reported sales is less than 83 percent.

\subsection{Basic OLS Estimation Results}

Our basic OLS regression results are presented in Table 3. The dependent variable in all specifications is a firm's Percent Reported Sales for tax purposes. Columns (1) to (3) report the results from using Difficulty of Access to External Finance as the measure of

21 Also, as argued by Beck, Lin, and Ma (2014), the major reasons for reforms in the financial sector are to improve credit assessment, to facilitate the access to credits markets, to lower the cost of external credits, and to enhance financial stability. Beck, Lin, and Ma (2014) do not find any evidence that tax evasion is a driving force for these reforms. 
financial constraints faced by the firms, and columns (4) to (6) present the corresponding

results using Cost of External Finance as an alternative measure of financial constraints

confronted the firms. In all regressions, we include country, industry, and year fixed effects to

control for unobserved heterogeneity and time fixed effects, and we report robust standard

error clustered at the country level in parentheses.

Column (1) reports the estimation results without adding any other explanatory

variables. As shown in column (1), the estimated coefficient of the Difficulty to Access to

External Finance is negative and statistically significant at 1 percent level, suggesting that

financial constraints tend to reduce the percentage of reported sales of the firms and so

increase firm tax evasion. This main result persists for the use of the Cost of External

Finance as the indicator of financial constraints in column (4). Quantitatively, the results in

columns (1) and (4) imply that a one category increase in the Difficulty of Access to External

Finance (or the Cost of External Finance) reduces the amount of sales reported for tax

purpose by 1.714 (or 1.231) percentage points. We then add to the model a richer set of firm

characteristics and country-level control variables in columns (2) and (3) and in columns (5)

and (6). ${ }^{22}$ Again, we find a generally negative and statistically significant impact of financial

constraints on firms' reported sales, supporting our hypothesis that financial constraints faced

22 For space concerns, the estimated coefficients for other control variables are not reported in Table 3, but their results are briefly summarized here. First, several firm-level variables have positive and statistically significant coefficients across different specifications, including firm age, size (the number of employees and annual sales), and locations. Second, Audited enters significantly in the regressions, and its significant positive coefficient suggests that firms tend to report lower tax evasion after their financial statements are previously audited by external auditors. Third, real GDP per capita and population both consistently enter with positive signs, indicating that higher levels of income and of population are associated with lower firm tax evasion. Finally, the significant and positive effect of Bank Cost to Income Ratio on a firm's Percent Reported Sales is consistent with the results of Beck, Lin, and Ma (2014), suggesting that the increase of efficiency in financial sectors will lower the incidence and extent of firm tax evasion. 
by the firms contribute to a higher level of tax evasion activities of the firms. ${ }^{23}$ However, endogeneity concerns surrounding the financial constraints may bias the OLS estimates, and so we next report instrumental variable estimations.

\subsection{Instrumental Variable Estimation Results}

The instrumental variable (IV) estimations are reported in Table 5. The Hansen J

Statistic of the over-identification restriction and the F-test in the first-stage estimation are implemented to test the validity of the instruments. For all specifications presented, the Hansen statistic (p-value) noted at the bottom of Table 5 is higher than 0.15 , implying that we cannot reject the null hypothesis of no correlation between the instruments and the error term in the regressions.

We then determine whether the five instruments are closely related to the financial constraints variables, which is another requirement for valid instruments. Table 4 reports the corresponding first-stage estimation results. We find that firms with overdue payments, larger share of non-conventional payments during the transactions, and more unanticipated lost sales are more likely to be confronted with more severe external financial constraints. While not all variables enter significantly in all six first-stage specifications, they are jointly significant at the 1 percent level in all six regressions, with first-stage F-statistics well above 10, suggesting that our IV estimates are not prone to the weak instrument concern.

As shown in Table 5, after we correct for potential endogeneity bias, financial constraints have a negative and statistically significant impact on a firm's Percent Reported

\footnotetext{
${ }^{23}$ With the inclusion of firm-level control variables in columns (2)-(3) and (5)-(6) of Table 3, the sample size for regressions is reduced substantially. In order to ensure that our results are not driven by the changes of sample size, we restrict all regressions to the same sample size. We find the results to be largely the same as the results in Table 3. These results are not reported but are available upon request.
} 
Sales for tax purposes in all specifications, regardless of the measures of financial constraints. In our preferred IV specifications in columns (3) and (6) of Table 5, the estimated coefficients for the Difficulty to Access to External Finance and the Cost of External Finance are -7.560 and -12.135 , respectively. These are economically significant magnitudes: a one category increase in the Difficulty of Access to External Finance reduces the amount of sales reported for tax purpose by 7.560 percentage points, while every additional category increase in the Cost of External Finance is associated with a decrease of 12.135 percentage points in reported sales. Note that the estimated coefficients for financial constraints in the IV estimations of Table 5 are much larger than those of the OLS estimations of Table 3, implying that endogeneity may bias the OLS estimates towards zero. This result is in line with previous research using the self-reported financial constraints, in which the OLS estimates are biased toward small effects of financial constraints and the instrumental variable estimates are much larger than the corresponding OLS estimates for financial constraints (de Mel, McKenzie, and Woodruff, 2008; Gorodnichenko and Schnitzer, 2013; Banerjee and Duflo, 2014).

\subsection{Robustness Checks}

\subsubsection{Alternative Measures of Firm Tax Evasion}

Tax evasion has many dimensions. So far, we have focused on the sales reported by firms for tax purpose. Since the BEEPS collects information on two other possible dimensions about tax evasion, we can also assess whether financial constraints affect a firm's decisions on reporting of its workforce and of its wage bill.

Similar to the Percent Reported Sales, we construct the two alternative evasion variables Percent Reported Workforce and Percent Reported Wage Bill using the answers to 
the following questions: "Recognizing the difficulties that many firms face in fully

complying with labor regulations, what percentage of total workforce (actual wage bill)

would you estimate the typical firm in your area of business reports for tax purposes?"24 We

repeat specification (1) using these two alternative measures of firm tax evasion as the

dependent variables. These results are reported in columns (1) to (4) of Table A2 in the

Online Appendix. As shown, we find similar results that financial constraints faced by the

firms negatively affect the percentage of reported workforce and percentage of reported wage

bill, confirming that our findings are not likely driven by the measurements of tax evasion.

In addition, we also generate a tax evasion dummy variable, which equals 1 if a firm

reports less than 100 percent of its sales for tax purpose and 0 otherwise. Results from the

two-step IV probit model are presented in columns (5) and (6) of Table A2 in the Online

Appendix. ${ }^{25}$ Once again, the estimates of financial constraints are significantly positive

across these specifications, indicating that the possibility of tax evasion increases with the

severity of financial constraints faced by the firms.

\subsubsection{Alternative Specifications}

We further test for the effect of financial constraints on firm tax evasion with different specifications and additional controls. All results are presented in Table A3 in the Online Appendix.

First, in order to capture specific country and industry time fixed effects, we control

24 The questions regarding to the firm's percent workforce or/and actual wage bill reported for tax purpose are collected only in the 2005 wave of the BEEPS, which results in a sharp decline in observations compared with the observations in baseline regressions using Percent Reported Sales as the dependent variable.

25 A two-step IV probit model is employed in the estimations since maximum likelihood estimation procedures may have difficulty converging (Newey, 1987). 
for specific country $\times$ time fixed effects, industry $\times$ time fixed effects, and the full set of interactions of these fixed effects. These specifications are shown in the first three rows of Table A3. These results are similar to the baseline IV results of Table 5.

Second, we consider many additional control variables to rule out the possibility of omitted variables. Firm tax evasion might be caused by transfer pricing and related party transactions (Desai and Dharmapala, 2006; Chen et al., 2010), especially for large multinational firms with multiple establishments. We address this concern by controlling for the number of establishments. There is also a concern that exporting firms might have self-selection effects toward reporting more severe financial constraints, because the long time needed for exporting induces tighter financial constraints for exporters than domestic firms (Feenstra, Li, and Yu, 2014). We address this concern by controlling for the share of exported goods in total sales. We include a dummy variable indicating whether the firm competes in the national or the local market and also a dummy variable indicating whether the firm is a member of a business association or chamber of commerce. These variables aim to capture the potential simultaneous effects caused by the factors associated with the firm's specific characteristics on both firm tax evasion and financial constraints. For example, a firm competing in a national market may have softer financial constraints because banks are well informed of the firm's productivity and risks; it may also imply that the firm is less involved with evasion activities because of the supervision from the public (Goerke and Runkel, 2011). We also control for the time senior managers spent dealing with government officials as a 
proxy of quality of infrastructure and institution. ${ }^{26}$ To preclude the concern that the effect of

financial constraints might be distorted by other dimensions of financial development, we

control for the ratio of stock market capitalization to GDP and the ratio of bank credit to bank

deposits as proxies for the depth and stability of the financial market. Finally, we include the

Boone Indicator and the Lerner Index, which measure competition and market power,

respectively in financial markets. ${ }^{27}$

As shown in Table A3 in the Online Appendix, even with all these additional controls

the estimated effect of financial constraints on firm tax evasion is strongly consistent with our

baseline IV estimation results in Table 5.

\subsubsection{Extended Sample}

Recall that the World Bank Enterprise Survey (WBES) serves as a potential

alternative source of data for the study. The WBES covers an even larger number of countries

and years. However, the WBES does not contain for all years some of the information for the

key instruments we require, which prevents us from using this dataset for our main analysis. ${ }^{28}$

Nevertheless, we rely on the dataset from the WBES to check the robustness of our main

26 The variable Manager's Time Spent with Officials is constructed from answers to the question: "What percent of senior management's time over the last 12 months was spent in dealing with public officials about the application and interpretation of laws and regulations and to get or to maintain access to public services?"

27 The Boone Indicator is a measure of the degree of competition, based on profit-efficiency in the banking market and calculated as the elasticity of profits to marginal costs. An increase in the Boone Indicator implies a deterioration of the competitive conduct of financial intermediaries. For more information, see Boone (2008). The Lerner Index is a measure of market power in the banking market, and it is defined as the difference between output prices and marginal costs (relative to prices). Higher values of the Lerner index indicate less bank competition.

${ }^{28}$ More specifically, the WBES does not have questions regarding whether the firm currently has any payments overdue (by more than 90 days) for utilities, taxes, employees, and/or material input suppliers; the WBES also does not have questions regarding the share of non-conventional payments during transactions with customers and suppliers. Furthermore, the EBRD only reports indices of the speed of reforms in banking sector and non-bank financial institutions for 27 transitional countries, which is consistent with the country coverage in the 2002 and 2005 BEEPS. 
results by using only OLS estimations. In Panel A of Table A4 in the Online Appendix, we restrict the WBES dataset to the same period as the BEEPS dataset that we used previously, or the period 2002-2005, and we then repeat the OLS estimations. As indicated in the bottom of Table A4, even focusing on the same time period, the total observations from the WBES are much larger than the BEEPS dataset, while the main results obtained remain largely unchanged compared to the OLS results in Table 3.

Next, in Panel B of Table A4 in the Online Appendix, we utilize the full dataset from the WBES, containing information from more than 100 countries and for the years 2002-2010, to re-estimate the OLS estimations. Given that the survey question for the Cost of External Finance is not included in the questionnaires for most of the countries after 2005, we only report the results using the Difficulty of Access to External Finance as the measure of financial constraints. As shown in Panel B of Table A4, the negative and statistically significant effect of financial constraints on firm tax evasion reconfirms our previous findings. In sum, we conclude that our findings are not likely to be driven by country selection.

\subsection{Heterogeneous Effects}

To investigate the possible heterogeneous effects of financial constraints on firm tax evasion, we re-estimate our model using various subsamples, differentiating firms by firm ownership, size, age, and sector. To save space, in all estimations we only report results from the specifications equivalent to those in Columns (3) and (6) of Table 5 and using IV estimation. These results are reported in Table 6 .

First, we re-estimate the baseline specification separately for private enterprises and 
state-owned (SOEs) and/or foreign enterprises. ${ }^{29}$ The results in columns (1) and (2) of Table 6 show that the estimated coefficient of financial constraints is statistically more significant for private firms than SOEs and/or foreign firms. These results suggest that both SOEs and foreign firms are less likely than private firms to experience financial constraints because they may have relatively easy to access to credit markets by asking for government intervention for SOEs or by getting credits from a parent company for foreign firms (Harrison and McMillan, 2003; Gorodnichenko and Schnitzer, 2013). Thus both SOEs and foreign firms should have less incentive to evade taxes. Quantitatively, depending on the measurements of financial constraints, the estimated effect of financial constraints for private firms is almost double to triple as large as that for SOEs and/or foreign firms and statistically and significantly different with a p-value below or close to 0.1 .

Second, we separate the firms by their sizes. Firms with 2 to 49 employees are classified as small firms, while those with more than 49 employees are regarded as medium and large firms. ${ }^{30}$ Firm size has often been used as a firm characteristic by which more or less financially constrained firms may be classified (Bose, 1998; Straub, 2005; Dabla-Norris, Gradstein, and Inchauste, 2008). The regression results in columns (3) and (4) of Table 6 show that, while financial constraints have a significantly negative effect on reported sales for both small and large firms, the quantitative effect of financial constraints in small firms is much larger than that in large firms. This result is consistent with previous studies that small firms are more likely to experience difficulty in getting access to finance (Hadlock and Pierce,

29 Firm ownership is defined by the largest shareholder of a firm, as provided directly by the survey.

30 These are the categories defined by the BEEPS. 
2010), and so smaller firms face stronger incentives to accumulate internal funds for

growth/development. Also, smaller firms are often subject to less tax auditing compared to larger firms.

Third, we separate the firms by their ages. As with firm size, firm age is another criterion used to classify how much the firm is financially constrained. We split the sample into deciles based on the age of a firm, and we compare the bottom three ("young" firms) deciles to the top three ("old" firms) deciles. As shown in columns (5) and (6) of Table 6, we find that firm tax evasion responses to financial constraints are more sensitive for young firms than old firms. The rationale for this is similar to the case of firm size; that is, young firms have a shorter credit history and so are more likely to experience difficulty in getting access to finance.

Finally, we separate the firms into two sectoral categories, manufacturing and services. Although we hypothesize that manufacturing firms may be more likely to suffer from liquidity constraints than firms in the service sector, our results in columns (7) and (8) of Table 6 do not seem to support this conjecture, since the estimated coefficient on financial constraints for manufacturing firms is not statistically different from that for service firms. ${ }^{31}$

\subsection{Suggestive Evidence on Possible Channels of the Impact}

What are the channels by which financial constraints faced by the firms lead to a higher level of firm tax evasion? Identifying these channels is difficult. While we are not able to fully uncover the exact working channels, we examine several possibilities, in some

31 Gorodnichenko and Schnitzer (2013) also find similar effects of financial constraints on firm innovation for firms in both manufacturing and service industries. 
additional exploratory estimations.

We suggest that there might be at least three active channels. First, a firm facing financial constraints seems more likely to reduce its information disclosure in the banking system (Hubbard, 1998; Healy and Palepu, 2001; Beck, Demirguc-Kunt, and Peria, 2007; Beck, Lin, and Ma, 2014). By doing so, the firm reduces any information on misreported financial statements or similar misconduct operations and so avoids tax obligations and other official rules. ${ }^{32}$ Second, a financially constrained firm is more likely to conduct business in cash, and indeed a firm facing financial constraints may shift more of its business into cash transactions in order to avoid paying taxes. ${ }^{33}$ Third, a financially constrained firm may attempt to lobby the government for a lower tax auditing probability (Beck, Demirguc-Kunt, and Levine, 2006; Barth et al., 2009), or even to bribe public officials for less tax enforcement (Uslaner, 2010; Alm, Martinez-Vazquez, and McClellan, 2016).

These channels may manifest themselves in several ways. The first channel suggests that financially constrained firms may reduce information disclosure through the banking system in order to avoid official rules (such as red tape) and tax obligations. To shed light on this possible channel, we utilize two dummy variables in the dataset, which indicate whether the firms have a saving/checking account, as proxies for information disclosure through the banking system, and we employ them as dependent variables in additional estimations. ${ }^{34}$

${ }^{32}$ For example, Kenyon (2008) finds evidence that tax-evading firms are less likely to participate in financial markets because they are concerned about information disclosure that may alert tax authorities.

33 For example, Denis and Sibilkov (2010) find that financially constrained firms tend to have greater cash holdings than unconstrained firms. Also, Gordon and Li (2009) claim that a typical way for firms to avoid paying taxes is to shift their business into cash transactions and avoid making use of the financial sector, resulting in no paper trails or bank records that the government can use to enforce tax laws.

34 The full question asked in the BEEPS is: "Does your establishment have a checking (saving) account? Yes/No". Admittedly, whether a firm has a checking or saving account in the banks cannot exactly capture all the information the firm would like to share with the financial sector. However, this variable reflects to some 
Results from a two-step IV probit model are reported in Panel A of Table 7. In line with our prediction, the negative and statistically significant estimates of financial constraints suggest that firms reduce their probability to open (or keep) a saving or checking account in the banks in response to the emergence of financial constraints. Thus, the less effective information being shared through the banking system helps firm hiding larger share of their sales and evading more taxes (Beck, Lin, and Ma, 2014).

The second channel suggests that financially constrained firms may rely more heavily on cash transactions. Accordingly, a firm facing strong incentives to accumulate internal funds because of financial constraints may shift more of its business into cash transactions in order to avoid paying taxes. To capture this possible channel, Panel B in Table 7 presents the effect of financial constraints on the share of cash used during the firm's transactions with suppliers and customers under the same framework of the baseline specification. ${ }^{35}$ We find that more financially constrained firms are associated with a larger share of transactions in cash with their suppliers, but not transactions with their customers. ${ }^{36}$ This finding is in line with the notion that it is usually customers who dominate the forms of transactions. Thus, it may be reasonable to observe that a firm has the capability to change the transaction method to cash when it deals with its suppliers, but the firm may have less to say when dealing with customers, where the firm may have to accept the transaction method preferred by the

extent a firm's willingness to disclose financial statements and cash flow status to the banks and also to the public.

35 The dependent variables are drawn from the responses to the question: "What share of your purchase from supplier (sales to customers) over the last 12 months was ultimately settled by cash?"

36 The share of cash used in transaction with suppliers and customers is directly correlated with one of the instruments (i.e., the share of non-conventional payments) that we employed for the financial constraints variables. As a result, we exclude the share of non-conventional payments from the instrument list for the estimations in Panel B of Table 7. 
customers.

The third channel suggests that financially constrained firm may increase their bribe activities. Our conjecture is that more financially constrained firms may utilize higher levels of bribe activities to public officials in exchange for a lower level of tax enforcement from the governments, as a way to accumulate internal funds. We use two primary measures of bribe activities of the firms as dependent variables: the percentage of sales paid in unofficial payment to public officials ${ }^{37}$ and the frequency of bribery. ${ }^{38}$ The results in Panel C of Table 7 indicate that financial constraints have a positive and significant impact on bribes in all specifications, regardless of the use of different measures of bribe activities of the firms. These results support our argument that financially constrained firms are more likely to be involved with bribe activities, which, as argued by Alm, Martinez-Vazquez, and McClellan (2016), facilitates firm tax evasion. ${ }^{39}$

Note this discussion of the possible channels is somewhat speculative. Given data availability, we are not able to fully identify the channels in a more compelling way. For example, our measure of firm information disclosure by using dummy variables for the presence of a firm saving or checking account cannot capture the true extent of information disclosure across firms. Even so, we believe that this analysis provides tentative evidence on the possible channels through which financial constraints may operate.

37 We have also employed the percentage of contract value paid in unofficial payment to public officials as an alternative measure of bribe activities of the firms, with largely unchanged results. These results are not reported but available upon request.

38 The percentage of sales paid in unofficial payment to public officials is constructed using the following questions of the BEEPS: "On average, what percent of total annual sales do firm's like yours typically pay in unofficial payments/gifts to public officials"? The frequency of bribery is a self-reported measure of frequency of unofficial payments/gifts that a firm makes to deal with taxes and tax collection as evaluated on a scale ranging from 1 ("Never") to 6 ("Always").

39 Note that Alm, Martinez-Vazquez, and McClellan (2016) also find evidence that corruption may exacerbate firm tax evasion, mainly because corrupt officials seek more income via bribes and loosen tax enforcement. 


\section{$\underline{\text { 5. Conclusions }}$}

How do financial market constraints affect firm tax evasion? Our analysis draws on the recent experience of firms in countries across the world, in order to estimate the impact of financial constraints on firm evasion decision, controlling for time varying controls and for time-invariant industry and country characteristics. We find strong evidence that more financially constrained firms are more likely to be involved in tax evasion activities, largely because evasion helps the firms deal with financing issues created by financial constraints. The effect is stronger for firms of private ownership, of smaller in size, and of a younger age. We also find suggestive evidence on the channels through which the impact of financial constraints on firm tax evasion may operate. In particular, we find that firms facing financial constraints are more likely to reduce information disclosure in the banking system, more likely to conduct business in cash in order to the paper trail of transactions, and more likely to lobby the government for a lower tax probability of tax audit.

We believe that these are novel results in several ways. They confirm the importance of financial markets in a dimension of firm behavior (e.g., tax evasion) that has not always been considered. They provide revealing if not definitive support for the ways in which these constraints may work. Of perhaps most importance, they extend the analysis of tax evasion beyond individuals to firms, an area that has until recently languished.

Even so, we must admit that our results are certainly not definitive. The measures of evasion are based on self-reported responses to indirect survey questions on evasion, rather than on formal and direct audit data. Even the measures of financial constraints are derived 
from self-reports, as are many of the control variables. The data also come from a specific sample of countries for a specific time period, and generalization beyond these countries and this time are always risky. ${ }^{40}$ We attempt to control for potential endogeneity concerns, but most any instrument can be criticized along some dimension. We also control for many driving factors, but we cannot control for all potentially relevant causal factors (e.g., penalty rates on tax evasion). Our channel analysis certainly indicates the potential importance of the channels that we test, but we concede that demonstrating clear-cut causality is a challenge.

Overall, then, we believe that our estimation results are quite robust across the many specifications that we tested, but we acknowledge that most any empirical results can be viewed as exploratory, and ours are no exception.

Given these concerns, it is important to extend our analysis to still other countries, still other time periods, still other explanatory variables, and still other instruments. The use of administrative data that provide direct measures of firm tax evasion would be an especially useful extension of our work, and such data are becoming increasingly available. We hope to make progress on these extensions in future work.

Our findings have important policy implications, especially for developing countries seeking to design policies to reduce firm tax evasion. The obvious, standard, and traditional policy to reduce evasion, whether of individuals or of firms, is greater enforcement, in which the policy emphasis is on the repression of illegal behavior through frequent audits and stiff penalties. However, recent research on tax evasion suggests that there are alternatives to such

${ }^{40}$ More generally, Alm (2017) argues that any answers that emerge from empirical research apply only to the specific setting that is being considered; that is, specific circumstances differ so profoundly across individuals, firms, markets, countries, and time that most any attempt to take conclusions from a single study and apply them in all circumstances will lead to profoundly misleading policy recommendations. 
an "enforcement paradigm" for tax administration (Alm, 2018). This research indicates that tax evasion can be reduced via two additional paradigms: a "service paradigm" that recognizes the role of tax administration as a facilitator and a provider of services for taxpayer-citizens, and a "trust paradigm" that sees the taxpayer-citizen as a member of a larger group of individuals all of whose behaviors depend on their moral values and their perceptions of the quality, credibility, and reliability of societal institutions. These two newer paradigms are consistent with an alternative policy to reduce tax evasion that moves beyond enforcement: improve credit markets. Such a policy would be consistent both with providing better services and with improving societal institutions. It is also a policy with some obvious benefits. In addition to the demonstrated effects of better credit markets on overall economic performance, another benefit would be reduced firm tax evasion. For governments eager to improve tax compliance, this alternative policy has clear advantages. It is also one that has seldom been applied, at least in the context of firm tax evasion. 


\section{$\underline{\text { References }}$}

Allingham, Michael G., and Agnar Sandmo. 1972. Income tax evasion: A theoretical analysis. Journal of Public Economics 1 (3-4): 323-338.

Alm, James. 2012. Measuring, explaining, and controlling tax evasion: Lessons from theory, experiments, and field studies. International Tax and Public Finance 19 (1): 54-77.

Alm, James. 2017. Is economics useful for public policy? Southern Economic Journal 83 (4): 835-854.

Alm, James. 2018. What motivates tax compliance? Department of Economics Working Paper. New Orleans, LA: Tulane University

Alm, James, Calvin Blackwell, and Michael McKee. 2004. Audit selection and firm compliance with a broad-based sales tax. National Tax Journal 57 (2): 209-227.

Alm, James, Jorge Martinez-Vazquez, and Chandler McClellan. 2016. Corruption and firm tax evasion. Journal of Economic Behavior \& Organization 124: 146-163.

Andreoni, James, Brian Erard, and Jonathan Feinstein. 1998. Tax compliance. The Journal of Economic Literature 36 (2): 818-860.

Banerjee, Abhijit V., and Esther Duflo. 2014. Do firms want to borrow more? Testing credit constraints using a directed lending program. The Review of Economic Studies 81 (2): 572-607.

Barth, James, Chen Lin, Ping Lin, and Frank Song. 2009. Corruption in bank lending to firms: Cross-country micro-evidence on the beneficial role of competition and information sharing. Journal of Financial Economics 91 (3): 361-388.

Baumann, Florian, and Tim Friehe. 2010. Tax evasion, investment, and firm activity. Finanzarchiv/Public Finance Analysis 66 (1): 1-14.

Beck, Thorsten, Asli Demirguc-Kunt, and Ross Levine. 2006. Bank supervision and corruption in lending. Journal of Monetary Economics 53 (8): 2131-2163.

Beck, Thorsten, Asli Demirguc-Kunt, and Vojislav Maksimovic. 2005. Financial and legal constraints to firm growth: Does size matter? Journal of Finance 60 (1): 137-177.

Beck, Thorsten, Asli Demirguc-Kunt, and Maria S. M. Peria. 2007. Reaching out: Access to and use of banking services across countries. Journal of Financial Economics 85 (1): 234-266.

Beck, Thorsten, Chen Lin, and Yue Ma. 2014. Why do firms evade taxes? The role of information sharing and financial sector outreach. The Journal of Finance 69 (2): 763-817.

Best, Michael C., Anne Brockmeyer, Henrik J. Kleven, Johannes Spinnewijn, and Mazhar Waseem. 2015. Production versus revenue efficiency with limited tax capacity: Theory and evidence from Pakistan. The Journal of Political Economy 123 (6): 1311-1355.

Boone, Jan. 2008. A new way to measure competition. The Economic Journal 118 (531): 1245-1261.

Bose, Pinaki. 1998. Formal-informal sector interaction in rural credit markets. Journal of Development Economics 56 (2): 265-280.

Blackburn, Keith, Niloy Bose, and Salvatore Capasso. 2012. Tax evasion, the underground 
economy and financial development. Journal of Economic Behavior \& Organization 83 (2): 243-253.

Brown, Martin, Tullio Jappelli, and Marco Pagano. 2009. Information sharing and credit: Firm-level evidence from transition countries. Journal of Financial Intermediation 18 (2): 151-172.

Carillo, Paul, Dina Pomeranz, and Monica Singhal. 2017. Dodging the taxman: Firm misreporting and limits to tax enforcement. American Economic Journal: Applied Economics 9 (2): 144-164.

Chen, Shuping, Xia Chen, Qjang Cheng, and Terry Shevlin. 2010. Are family firms more tax aggressive than non-family firms? Journal of Financial Economics 95 (1): 41-61.

Cowell, Frank A. 1990. Cheating the Government: The Economics of Evasion. Cambridge, MA: The MIT Press.

Crocker, Keith J., and Joel Slemrod. 2005. Corporate tax evasion with agency costs. Journal of Public Economics 89 (9-10): 1593-1610.

Dabla-Norris, Era, Mark Gradstein, and Gabriela Inchauste. 2008. What causes firms to hide output? The determinants of informality. Journal of Development Economics 85 (1): $1-27$.

de Mel, Suresh, David McKenzie, and Christopher Woodruff. 2008. Returns to capital in microenterprises: Evidence from a field experiment. The Quarterly Journal of Economics 123 (4): 1329-1372.

Denis, David. J., and Valeriy Sibilkov. 2010. Financial constraints, investment, and the value of cash holdings. Review of Financial Studies 23 (1): 247-269.

Desai, Mihir, and Dhammika Dharmapala. 2006. Corporate tax avoidance and high-powered incentives. Journal of Financial Economics 79 (1): 145-179.

Edwards, Alexander, Casey Schwab, and Terry Shevlin. 2016. Financial constraints and cash tax savings. The Accounting Review 91 (3): 859-881.

Elffers, Henk, Russell H. Weigel, and Dick J. Hessing. 1987. The consequences of different strategies for measuring tax evasion behavior. Journal of Economic Psychology 8 (3): 311-337.

Feenstra, Robert C., Zhiyuan Li, and Miaojie Yu. 2014. Exports and credit constraints under incomplete information: Theory and evidence from China. The Review of Economics and Statistics 96 (4): 729-744.

Goerke, Laszlo, and Marco Runkel. 2006. Profit tax evasion under oligopoly with endogenous market structure. National Tax Journal 59 (4): 851-857

Goerke, Laszlo, and Marco Runkel. 2011. Tax evasion and competition. Scottish Journal of Political Economy 58 (5): 711-736.

Gordon, Roger, and Wei Li. 2009. Tax structures in developing countries: Many puzzles and a possible explanation. Journal of Public Economics 93 (7-8): 855-866.

Gorodnichenko, Yuriy, and Monika Schnitzer. 2013. Financial constraints and innovation: Why poor countries don't catch up. Journal of the European Economic Association 11 (5): 1115-1152.

Hadlock, Charles J., and Joshua R. Pierce. 2010. New evidence on measuring financial constraints: Moving beyond the KZ index. The Review of Financial Studies 23 (5): 
1909-1940.

Harrison, Ann E., and Margaret McMillan. 2003. Does direct foreign investment affect domestic credit constraints? Journal of International Economics 61 (1): 73-100.

Healy, Paul M., and Krishna G. Palepu. 2001. Information asymmetry, corporate disclosure, and the capital markets: A review of the empirical disclosure literature. Journal of Accounting and Economics 31 (1-3): 405-440.

Hubbard, R. Glenn. 1998. Capital market imperfections and investment. The Journal of Economic Literature 36 (1): 193-225.

Johnson, Simon, Daniel Kaufmann, John McMillan, and Christopher Woodruff. 2000. Why do firms hide? Bribes and unofficial activity after communism. Journal of Public Economics 76 (3): 495-520.

Kenyon, Thomas. 2008. Tax evasion, disclosure, and participation in financial markets: Evidence from Brazilian firms. World Development 36 (11): 2512-2525.

Kundt, Thorben, Florian Misch, and Birger Nerré. 2017. Re-assessing the merits of measuring tax evasion through business surveys: An application of the crosswise model. International Tax and Public Finance 24 (1):112-133.

Newey, Whitney K. 1987. Efficient estimation of limited dependent variable models with endogenous explanatory variables. Journal of Econometrics 36 (3): 231-250.

Mayberry, Michael. 2012. Tax avoidance and investment: Distinguishing the effects of capital rationing and overinvestment. Doctoral dissertation, Texas A\&M University.

Modigliani, Franco, and Merton H. Miller. 1958. The cost of capital, corporation finance, and the theory of investment. The American Economic Review 48 (3):261-297.Murray, Matthew N. 1995. Sales tax compliance and audit selection. National Tax Journal 48 (4): 515-530.

Pomeranz, Dina. 2015. No taxation without information: Deterrence and self-enforcement in the value added tax. The American Economic Review 105 (8): 2539-2569.

Quintin, Erwan. 2008. Contract enforcement and the size of the informal economy. Economic Theory 37 (3): 395-416.

Rice, Eric M. 1992. The corporate tax gap: Evidence on tax compliance by small corporations. In Joel Slemrod (ed.), Why People Pay Taxes. Ann Arbor, MI: The University of Michigan Press, 125-161.

Sandmo, Agnar. 2005. The theory of tax evasion: A retrospective view. National Tax Journal 58 (4): 643-663.

Sandmo, Agnar. 2012. An evasive topic: Theorizing about the hidden economy. International Tax and Public Finance 19 (1): 5-24.

Slemrod, Joel, and Caroline Weber. 2012. Evidence of the invisible: Toward a credibility revolution in the empirical analysis of tax evasion and the informal economy. International Tax and Public Finance 12 (1): 25-53.

Slemrod, Joel, and Shlomo Yitzhaki. 2002. Tax avoidance, evasion, and administration. In Alan J. Auerbach and Martin Feldstein (eds.), Handbook of Public Economics, Volume 4. Amsterdam, London, and New York: Elsevier Publishing, 1423-1470.

Straub, Stéphane. 2005. Informal sector: The credit market channel. Journal of Development Economics 78 (2): 299-321. 
Uslaner, Eric M. 2010. Tax evasion, corruption, and the social contract in transition. In James Alm, Jorge Martinez-Vazquez, and Benno Torgler (eds.), Developing Alternative Frameworks for Explaining Tax Compliance. New York, NY: Routledge International Studies in Money and Banking, 174-190.

Wang, Leonard F. S., and John L. Conant. 1988. Corporate tax evasion and output decisions of the uncertain monopolist. National Tax Journal 41 (4): 579-581. 
Figure 1. Financial Constraints and Percent Reported Sales
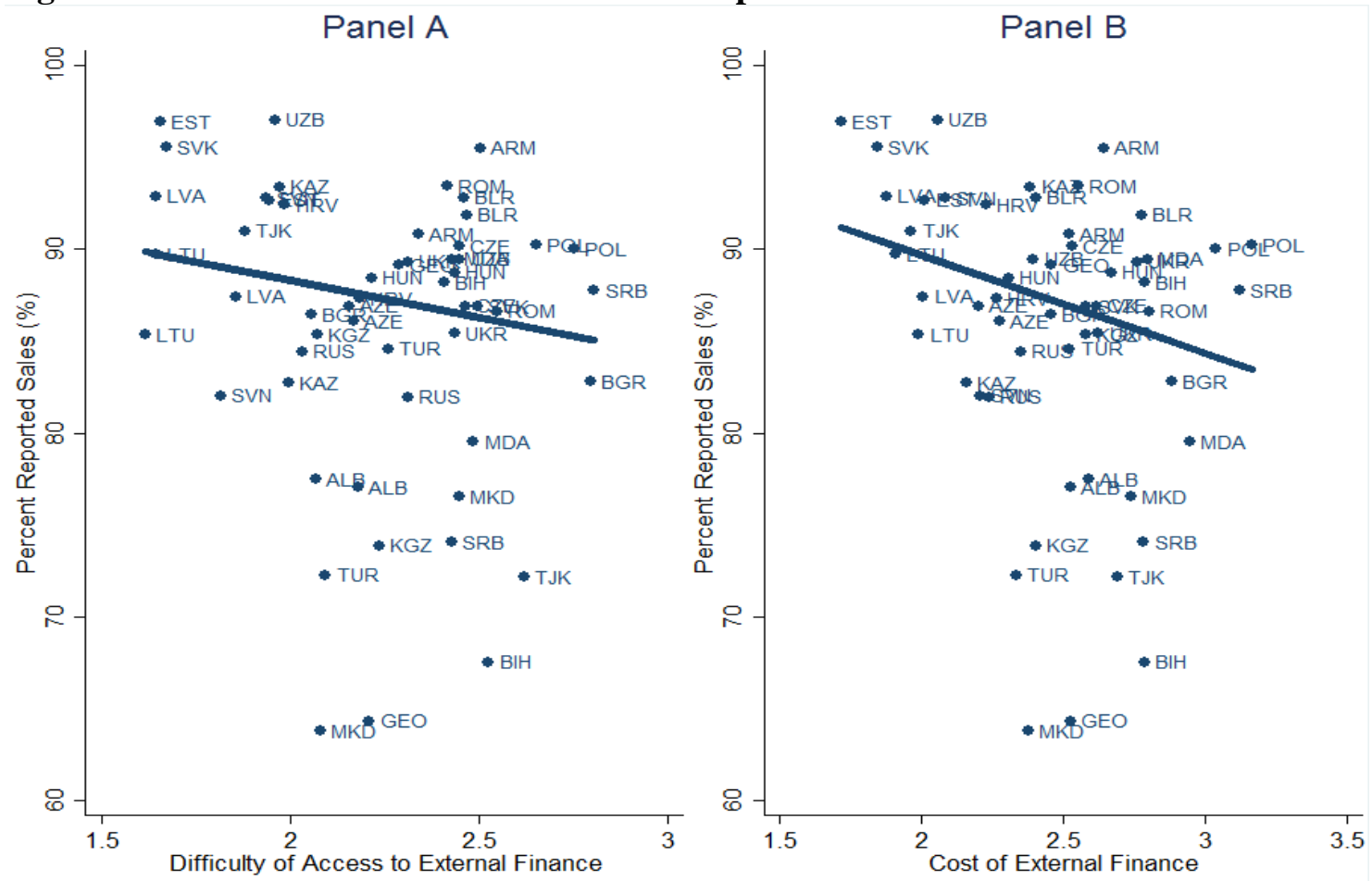
Table 1. Variables, Descriptions, and Summary Statistics

\begin{tabular}{|c|c|c|c|c|}
\hline Variable & Description & Observations & Mean & Standard Deviation \\
\hline \multicolumn{5}{|l|}{ Evasion Variables } \\
\hline Percent Reported Sales & Percent of a firm's sales reported for tax purposes & 16,186 & 87.310 & 21.319 \\
\hline Percent Reported Workforce & Percent of a firm's workforce reported for tax purposes & 10,336 & 91.017 & 17.854 \\
\hline Percent Reported Wage Bill & Percent of a firm's wage bill reported for tax purposes & 10,295 & 88.144 & 20.409 \\
\hline Evasion & $\begin{array}{l}\text { Dummy variable equal to } 1 \text { if a firm reports less than } 100 \text { percent of its sales } \\
\text { for tax purpose and } 0 \text { otherwise }\end{array}$ & 16,186 & 0.393 & 0.488 \\
\hline \multicolumn{5}{|l|}{ Measures of Financial Constraints } \\
\hline Difficulty of Access to External Finance & Difficulty of access to external finance as an obstacle to business & 16,616 & 2.249 & 1.144 \\
\hline Cost of External Finance & Cost of external finance as an obstacle to business & 16,730 & 2.480 & 1.135 \\
\hline \multicolumn{5}{|l|}{ Controls } \\
\hline $\ln ($ Age $)$ & Natural log of a firm's age & 17,418 & 2.482 & 0.728 \\
\hline $\ln ($ Labor $)$ & Natural log of a firm's permanent and temporary employees 36 months ago & 16,278 & 3.187 & 1.605 \\
\hline $\ln ($ Sales $)$ & Natural log of a firm's total sales (in U.S. dollars) & 12,922 & 5.941 & 2.026 \\
\hline Tax Rates as Obstacle & Tax rates as an obstacle to business (1-no obstacle, 4-major obstacle) & 17,172 & 2.724 & 1.117 \\
\hline Tax Regulations as Obstacle & Tax regulations as an obstacle to business (1-no obstacle, 4-major obstacle) & 16,995 & 2.474 & 1.137 \\
\hline Audited & $\begin{array}{l}\text { Dummy variable equal to } 1 \text { if a firm is checked and certified by an external } \\
\text { auditor and } 0 \text { otherwise }\end{array}$ & 17,037 & 0.505 & 0.500 \\
\hline $\ln$ (Population) & Natural log of population (in millions) at country level & 16,322 & 2.535 & 1.241 \\
\hline $\ln ($ Real GDP per Capita) & Natural log of real GDP per capita (in U.S. dollars) & 16,072 & 9.022 & 0.591 \\
\hline Corporate Income Tax Rate & Stationary corporate income tax rate & 16,928 & 22.907 & 6.002 \\
\hline Bank Concentration & $\begin{array}{l}\text { Assets of three largest commercial banks as a percent of total commercial } \\
\text { banking assets }\end{array}$ & 17,253 & 69.455 & 16.272 \\
\hline Bank Cost to Income Ratio & $\begin{array}{l}\text { Operating expenses of a bank as a percent of sum of net interest revenue and } \\
\text { other operating income }\end{array}$ & 17,253 & 56.757 & 13.653 \\
\hline
\end{tabular}




Capital
Other, Over 1,000,000
Other, 250,000-1,000,000
Other, 50,000-250,000
Under 50,000
Instruments
Overdue
Share of Non-conventional Payments
Lost Sales
EBRD Bank Reform
EBRD Non-bank Reform
Additional Controls
Association
Competition
Manager's Time Spent with Officials
In(Establishments)
Bxport
Lerner Index
Bank Loan Ratio
Chanels

\begin{tabular}{|c|c|c|c|}
\hline Dummy variable equal to 1 for a firm located in the capital city and 0 & 17,429 & 0.309 & 0.462 \\
\hline $\begin{array}{l}\text { Dummy variable equal to } 1 \text { for a firm located in a city with population over } 1 \\
\text { million and } 0 \text { otherwise }\end{array}$ & 17,429 & 0.060 & 0.238 \\
\hline $\begin{array}{l}\text { Dummy variable equal to } 1 \text { for a firm located in a city with population } \\
\text { between } 250,000-1,000,000 \text { and } 0 \text { otherwise }\end{array}$ & 17,429 & 0.153 & 0.360 \\
\hline $\begin{array}{l}\text { Dummy variable equal to } 1 \text { for a firm located in a city with population between } \\
50,000-250,000 \text { and } 0 \text { otherwise }\end{array}$ & 17,429 & 0.224 & 0.417 \\
\hline $\begin{array}{l}\text { Dummy variable equal to } 1 \text { for a firm located in a city with population under } \\
50,000 \text { and } 0 \text { otherwise }\end{array}$ & 17,429 & 0.253 & 0.435 \\
\hline Dummy variable equal to 1 if a firm has overdue payments and 0 otherwise & 17,306 & 0.166 & 0.372 \\
\hline Percent of a firm's payments settled by debt swaps or offsets and barters & 17,342 & 5.346 & 18.249 \\
\hline Percent of a firm's sales lost due to unexpected events & 17,429 & 0.017 & 0.055 \\
\hline Speed of reform in banking sector & 15,251 & 2.910 & 0.711 \\
\hline Speed of reform of non-bank financial institutions & 15,251 & 2.521 & 0.736 \\
\hline Dummy variable equal to 1 if a firm is a member of a business association and & 17,429 & 0.431 & 0.495 \\
\hline $\begin{array}{l}0 \text { otherwise } \\
\text { Dummy variable equal to } 1 \text { if a firm competes in the national market and } 0 \\
\text { otherwise }\end{array}$ & 17,093 & 0.702 & 0.457 \\
\hline Percent of time senior managers spent dealing with government officials & 16,476 & 5.821 & 10.624 \\
\hline Natural log of the number of a firm's establishments & 17,411 & 0.934 & 0.534 \\
\hline Percent of a firm's exports in sales & 17,383 & 10.439 & 24.376 \\
\hline Measure of degree of competition in the banking market & 17,253 & -0.135 & 0.180 \\
\hline Measure of market power in the banking market & 16,871 & 0.256 & 0.089 \\
\hline Ratio of stock market capitalization to GDP (\%) & 14,428 & 24.543 & 25.429 \\
\hline Ratio of bank credit to bank deposits (\%) & 16,869 & 101.270 & 50.711 \\
\hline
\end{tabular}




\begin{tabular}{|c|c|c|c|c|}
\hline Checking Account & $\begin{array}{l}\text { Dummy variable equal to } 1 \text { if a firm has a checking account in banks and } 0 \\
\text { otherwise }\end{array}$ & 9,655 & 0.821 & 0.384 \\
\hline Saving Account & $\begin{array}{l}\text { Dummy variable equal to } 1 \text { if a firm has a saving account in banks and } 0 \\
\text { otherwise }\end{array}$ & 9,655 & 0.239 & 0.427 \\
\hline Bribe to Public Officials (Percent of Total Sales) & Bribery of public officials as percent of sales & 15,691 & 1.149 & 2.727 \\
\hline Bribe to Public Officials (Percent of Contract Value) & Bribery of public officials as percent of contract value & 14,750 & 1.608 & 3.982 \\
\hline Frequency of Bribe & $\begin{array}{l}\text { Frequency of a firm's unofficial payments/gifts to deal with taxes and tax } \\
\text { collection }\end{array}$ & 15,826 & 1.923 & 1.345 \\
\hline Cash Used with Supplier & Natural log of percent of a firm's payments settled by cash with suppliers ${ }^{\mathrm{a}}$ & 10,538 & 2.196 & 1.971 \\
\hline Cash Used with Customer & Natural log of percent of a firm's payments settled by cash with customers ${ }^{\mathrm{a}}$ & 10,703 & 2.759 & 1.872 \\
\hline
\end{tabular}


Table 2. Number and Share of Firms Responding to Unanticipated Cash Flow Shock

\begin{tabular}{lccc}
\hline Responses & $\begin{array}{c}\text { Number of Firms } \\
\text { Reporting Responses }\end{array}$ & \multicolumn{2}{c}{$\begin{array}{c}\text { Total Number } \\
\text { of Firms in Sample }\end{array}$} \\
\hline Delaying payment to suppliers/utilities & 2,972 & 6,667 & $44.58 \%$ \\
Delaying payments to workers & 1,962 & 6,667 & $29.43 \%$ \\
Delaying payments to budget and extra-budgetary funds & 1,413 & 6,667 & $21.19 \%$ \\
Exchanging goods for goods & 1,678 & 6,667 & $25.17 \%$ \\
Obtaining credit from banks & 2,829 & 6,667 & $42.43 \%$ \\
Obtaining credit from suppliers & 2,513 & 6,667 & $37.69 \%$ \\
Liquidate short term financial assets & 1,784 & 6,667 & $26.76 \%$ \\
Issuing bills of exchange (e.g., veksels) & 554 & 6,667 & $8.31 \%$ \\
Obtaining credit from the government & 309 & 6,667 & $4.63 \%$ \\
Obtaining a subsidy from the government & 283 & 6,667 & $4.24 \%$ \\
\hline Note: The qui & & & Pent \\
\hline
\end{tabular}

Note: The question is "Now I would like to ask you a hypothetical question: Suppose that the incoming cash flow to your firm for the next quarter is $10 \%$ lower than you had expected. This cash flow is not permanently lost, but merely unexpectedly delayed. However, your working capital needs and level of production remain the same. Please look at this list and select at most 4 sources from which you would finance this gap. For each of the source selected, please indicate its importance." This question is not included in the 2005 survey questionnaire, so all firms listed in this table are from the 2002 BEEPS. 
Table 3. Basic OLS Estimates: The Effect of Financial Constraints on Firm Tax Evasion

\begin{tabular}{lcccccc}
\hline & \multicolumn{5}{c}{ Percent Reported Sales } \\
\cline { 2 - 7 } Dependent Variable & $\mathbf{( 1 )}$ & $\mathbf{( 2 )}$ & $\mathbf{( 3 )}$ & $\mathbf{( 4 )}$ & $\mathbf{( 5 )}$ & $\mathbf{( 6 )}$ \\
\hline Difficulty of Access to External Finance & $-1.714^{* * *}$ & $-0.869^{* * *}$ & $-0.843^{* * *}$ & & & \\
& $(0.189)$ & $(0.189)$ & $(0.186)$ & & & \\
Cost of External Finance & & & & $-1.231^{* * *}$ & -0.219 & $-0.295^{*}$ \\
& & & & $(0.174)$ & $(0.171)$ & $(0.159)$ \\
Firm-level Controls & & & & & \\
Country-level Controls & No & Yes & Yes & No & Yes & Yes \\
Country FE & No & No & Yes & No & No & Yes \\
Industry FE & Yes & Yes & Yes & Yes & Yes & Yes \\
Year FE & Yes & Yes & Yes & Yes & Yes & Yes \\
Observations & Yes & Yes & Yes & Yes & Yes & Yes \\
R-squared & 13,263 & 9,237 & 9,074 & 13,362 & 9,307 & 9,142
\end{tabular}

Note: The table reports estimates of coefficients from OLS regressions of the percent reported sales on the difficulty of access to external finance and the cost of external finance. Fixed effects for country, industry, and year are included in all regressions. Firm-level control variables include $\ln ($ Age $), \ln ($ Labor $), \ln (\operatorname{Sales})$, Tax Rates as Obstacle, Tax Administration as Obstacle, Audited, and a set of location dummy variables (Other, Over 1,000,000; Other, 250,000-1,000,000; Other, 50,000-250,000; Under 50,000). Country-level control variables include Corporate Income Tax Rate, In(Real GDP per Capita), In(Population), Bank Concentration, and Bank Cost to Income Ratio. Robust standard errors clustered at the country level are reported in parentheses. *, **, and $* * *$ denote the significance at the $10 \%, 5 \%$, and $1 \%$ level, respectively. 
Table 4. IV First-stage Estimation Results

\begin{tabular}{|c|c|c|c|c|c|c|}
\hline \multirow[t]{2}{*}{ Dependent Variable } & \multicolumn{3}{|c|}{ Difficulty of Access to External Finance } & \multicolumn{3}{|c|}{ Cost of External Finance } \\
\hline & (1) & (2) & (3) & (4) & (5) & (6) \\
\hline \multirow[t]{2}{*}{ Overdue } & $0.314 * * *$ & $0.279 * * *$ & $0.287 * * *$ & $0.255 * * *$ & $0.177 * * *$ & $0.186^{* * *}$ \\
\hline & $(0.041)$ & $(0.046)$ & $(0.047)$ & $(0.027)$ & $(0.021)$ & $(0.021)$ \\
\hline \multirow[t]{2}{*}{ Share of Non-conventional Payments } & $0.002 * * *$ & $0.002 * * *$ & $0.002 * * *$ & $0.002 * * *$ & $0.001 * * *$ & $0.001 * * *$ \\
\hline & $(0.001)$ & $(0.001)$ & $(0.001)$ & $(0.000)$ & $(0.000)$ & $(0.001)$ \\
\hline \multirow[t]{2}{*}{ Lost Sales } & $0.846 * * *$ & $0.361 *$ & $0.414 * *$ & $0.684 * * *$ & 0.211 & 0.244 \\
\hline & $(0.217)$ & $(0.200)$ & $(0.187)$ & $(0.225)$ & $(0.229)$ & $(0.215)$ \\
\hline \multirow[t]{2}{*}{ EBRD Bank Reform } & -0.167 & 0.080 & 0.069 & -0.333 & -0.023 & 0.038 \\
\hline & $(0.262)$ & $(0.285)$ & $(0.203)$ & $(0.264)$ & $(0.231)$ & $(0.205)$ \\
\hline \multirow[t]{2}{*}{ EBRD Non-bank Reform } & $0.461 * *$ & 0.017 & -0.223 & $0.571 * *$ & 0.084 & 0.052 \\
\hline & $(0.224)$ & $(0.268)$ & $(0.222)$ & $(0.248)$ & $(0.213)$ & $(0.187)$ \\
\hline Firm-level Controls & No & Yes & Yes & No & Yes & Yes \\
\hline Country-level Controls & No & No & Yes & No & No & Yes \\
\hline Country FE & Yes & Yes & Yes & Yes & Yes & Yes \\
\hline Industry FE & Yes & Yes & Yes & Yes & Yes & Yes \\
\hline Year FE & Yes & Yes & Yes & Yes & Yes & Yes \\
\hline IV-F Stat & 17.13 & 12.86 & 12.76 & 35.75 & 19.82 & 24.32 \\
\hline $\operatorname{Pr}>\mathrm{F}$ & 0.00 & 0.00 & 0.00 & 0.00 & 0.00 & 0.00 \\
\hline Observations & 13,263 & 9,237 & 9,074 & 13,362 & 9,307 & 9,142 \\
\hline
\end{tabular}

Note: The table reports estimates of coefficients from IV first-stage regressions of financial constraints on instrumental variables. Fixed effects for country, industry, and year are included in all regressions. Firm-level control variables include $\ln ($ Age $), \ln (\operatorname{Labor}), \ln ($ Sales $)$, Tax Rates as Obstacle, Tax Administration as Obstacle, Audited, and a set of location dummy variables (Other, Over 1,000,000; Other, 250,000-1,000,000; Other, 50,000-250,000; Under 50,000). Country-level control variables include Corporate Income Tax Rate, In(Real GDP per Capita), In(Population), Bank Concentration, and Bank Cost to Income Ratio. Robust standard errors clustered at the country level are reported in parentheses. *, **, and *** denote the significance at the $10 \%, 5 \%$, and $1 \%$ level, respectively. 
Table 5. IV Second-stage Estimates: The Effect of Financial Constraints on Tax Evasion

\begin{tabular}{lcccccc}
\hline & \multicolumn{7}{c}{ Percent Reported Sales } \\
\cline { 2 - 7 } & $\mathbf{( 1 )}$ & $\mathbf{( 2 )}$ & $\mathbf{( 3 )}$ & $\mathbf{( 4 )}$ & $\mathbf{( 5 )}$ & $\mathbf{( 6 )}$ \\
\hline Difficulty of Access to External Finance & $-8.656^{* * *}$ & $-8.806^{* * * *}$ & $-7.560^{* * *}$ & & & \\
& $(3.327)$ & $(2.996)$ & $(2.703)$ & & & \\
Cost of External Finance & & & & $-10.172^{* *}$ & $-14.404^{* * *}$ & $-12.135^{* *}$ \\
& & & & $(4.283)$ & $(5.215)$ & $(4.808)$ \\
& & & & & & \\
Firm-level Controls & No & Yes & Yes & No & Yes & Yes \\
Country-level Controls & No & No & Yes & No & No & Yes \\
Country FE & Yes & Yes & Yes & Yes & Yes & Yes \\
Industry FE & Yes & Yes & Yes & Yes & Yes & Yes \\
Year FE & Yes & Yes & Yes & Yes & Yes & Yes \\
Observations & 13,263 & 9,237 & 9,074 & 13,362 & 9,307 & 9,142 \\
R-squared & -0.133 & -0.140 & -0.087 & -0.221 & -0.453 & -0.309 \\
IV F-stat & 17.13 & 12.86 & 12.76 & 35.75 & 19.82 & 24.32 \\
Hansen J & 5.824 & 4.266 & 6.727 & 5.574 & 4.329 & 5.852 \\
P-value of Hansen J & 0.213 & 0.371 & 0.151 & 0.233 & 0.363 & 0.211 \\
\hline
\end{tabular}

Note: The table reports estimates of coefficients from IV second-stage regressions of the percent reported sales on the difficulty of access to external finance and the cost of external finance. Fixed effects for country, industry, and year are included in all regressions. Firm-level control variables include $\ln ($ Age $), \ln ($ Labor $), \ln ($ Sales $)$, Tax Rates as Obstacle, Tax Administration as Obstacle, Audited, and a set of location dummy variables (Other, Over 1,000,000; Other, 250,000-1,000,000; Other, 50,000-250,000; Under 50,000). Country-level control variables include Corporate Income Tax Rate, In(Real GDP per Capita), In(Population), Bank Concentration, and Bank Cost to Income Ratio. Robust standard errors clustered at the country level are reported in parentheses. *, **, and $* * *$ denote the significance at the $10 \%, 5 \%$, and $1 \%$ level, respectively. 
Table 6. Heterogeneity Effects of Financial Constraints on Tax Evasion

\begin{tabular}{|c|c|c|c|c|c|c|c|c|}
\hline & \multicolumn{2}{|c|}{ Ownership } & \multicolumn{2}{|c|}{ Firm Size } & \multicolumn{2}{|c|}{ Firm Age } & \multicolumn{2}{|c|}{ Sector } \\
\hline & Private & SOE\&Foreign & Small & Large & Young & Old & Manufacturing & Services \\
\hline & (1) & (2) & (3) & (4) & (5) & (6) & $(7)$ & (8) \\
\hline \multirow[t]{2}{*}{ Difficulty of Access to External Finance } & $-11.542 * * *$ & $-3.897 *$ & $-14.661 * * *$ & $-4.201 * * *$ & $-12.483 * * *$ & $-5.277 * *$ & $-7.154 * *$ & $-9.119 * *$ \\
\hline & $(3.413)$ & $(2.170)$ & $(4.704)$ & $(1.553)$ & $(3.005)$ & $(2.557)$ & $(3.459)$ & $(4.429)$ \\
\hline P-value & \multicolumn{2}{|c|}{0.027} & \multicolumn{2}{|c|}{0.006} & \multicolumn{2}{|c|}{0.028} & \multicolumn{2}{|c|}{0.653} \\
\hline Observations & 7,290 & 5,498 & 9,195 & 4,068 & 4,864 & 3,463 & 4,575 & 6,383 \\
\hline R-squared & -0.316 & -0.009 & -0.488 & -0.007 & -0.304 & -0.038 & -0.095 & -0.142 \\
\hline IV F-stat & 13.96 & 11.26 & 14.51 & 16.25 & 9.241 & 12.31 & 19.74 & 9.663 \\
\hline Hansen J & 2.744 & 6.854 & 5.018 & 4.751 & 5.188 & 3.739 & 6.143 & 4.088 \\
\hline P-value of Hansen $J$ & 0.602 & 0.144 & 0.285 & 0.314 & 0.269 & 0.442 & 0.189 & 0.394 \\
\hline \multirow[t]{2}{*}{ Cost of External Finance } & $-11.571 * * *$ & -4.951 & $-14.849^{* * *}$ & $-6.233 * * *$ & $-13.875^{* * *}$ & $-8.528 * *$ & $-11.161^{*}$ & $-10.112 * *$ \\
\hline & $(3.348)$ & (3.132) & $(5.654)$ & $(2.334)$ & $(4.070)$ & (3.616) & $(6.177)$ & $(4.840)$ \\
\hline P-value & \multicolumn{2}{|c|}{0.105} & \multicolumn{2}{|c|}{0.054} & \multicolumn{2}{|c|}{0.309} & \multicolumn{2}{|c|}{0.839} \\
\hline Observations & 7,339 & 5,533 & 9,252 & 4,110 & 4,873 & 3,504 & 4,612 & 6,440 \\
\hline R-squared & -0.341 & -0.040 & -0.515 & -0.072 & -0.402 & -0.186 & -0.301 & -0.211 \\
\hline IV F-stat & 10.31 & 17.94 & 29.77 & 20.88 & 18.34 & 15.56 & 8.732 & 13.45 \\
\hline Hansen J & 2.875 & 6.358 & 5.346 & 5.034 & 5.279 & 3.292 & 6.594 & 4.716 \\
\hline P-value of Hansen J & 0.579 & 0.174 & 0.254 & 0.284 & 0.260 & 0.510 & 0.159 & 0.318 \\
\hline
\end{tabular}


Table 7. Channel Analysis

Panel A: Information Disclosure

Dependent Variable

Saving Account

Checking Account

(1)

(2)

(3)

(4)

Difficulty of Access to External Finance

$-0.629 * * *$

$-1.171 * * *$

(0.196)

$(0.265)$

Cost of External Finance

$-1.193^{* * *}$

$-2.500 * * *$

(0.409)

Observations

5,917

5,955

5,388

5,429

Panel B: Cash Used in Transactions

Dependent Variable

Cash Used with Suppliers

Cash Used with Customers

(5)

Difficulty of Access to External Finance

$0.496 * * *$

(0.169)
(6)

$(6)$

$-0.038$

(0.176)

$0.772 * *$

$(0.377)$

5,876

$-0.013$

19.00

0.253

0.615

0.521

P-value of Hansen J

Panel C: Corruption

\begin{tabular}{llccc} 
R-squared & 0.102 & -0.013 & 5,915 & 5,953 \\
IV F-stat & 36.42 & 19.00 & 0.123 & 0.114 \\
Hansen J & 0.411 & 0.253 & 0.127 & 19.20 \\
P-value of Hansen J & 0.521 & 0.615 & 0.721 & 0.111 \\
\hline
\end{tabular}

Dependent Variable

\section{Bribe to Public Officials}

(Percent of Total Sales)

(9)

$1.228 * * *$

(0.275)

(10)

Difficulty of Access to External Finance

Cost of External Finance

(0)

$1.659 * * *$
Frequency of Bribery

(11)

$0.291 * * *$

(0.103)

5,915

0.123

36.44

0.127

0.721

$-0.152$

(0.360)

5,953

0.114

19.20

0.111

0.739

(8)

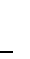

$0.390 * * *$

(0.373)

(0.137)

Observations

8,964

9,015

8,938

8,992

R-squared

$-0.158$

$-0.305$

0.042

0.018

IV F-stat

15.65

26.65

12.64

19.78

8.689

9.346

5.480

5.412

0.0694

0.0530

0.241

0.248

P-value of Hansen $\mathbf{J}$

Note: The table reports estimates of coefficients from IV regressions of the dependent variables on the difficulty of access to external finance and the cost of external finance. The Newey's two-step estimator is employed in IV probit regressions in Panel A since the maximum likelihood estimator may have difficulty in converging. Fixed effects for country, industry, and year, as well as all other controls at the firm-level and the country-level, are included in all regressions, as described in specification (1) in the text. Firm-level control variables include $\ln ($ Age), $\ln ($ Labor), $\ln ($ Sales), Tax Rates as Obstacle, Tax Administration as Obstacle, Audited, and a set of location dummy variables. Country-level control variables include Corporate Income Tax Rate, $\ln ($ Real GDP per Capita), In(Population), Bank Concentration, and Bank Cost to Income Ratio. Robust standard errors clustered at the country level are reported in parentheses. *, **, and $* * *$ denote the significance at the $10 \%, 5 \%$, and $1 \%$ level, respectively. 


\section{Online Appendix}

Figure A1. Financial Constraints and Financial Development
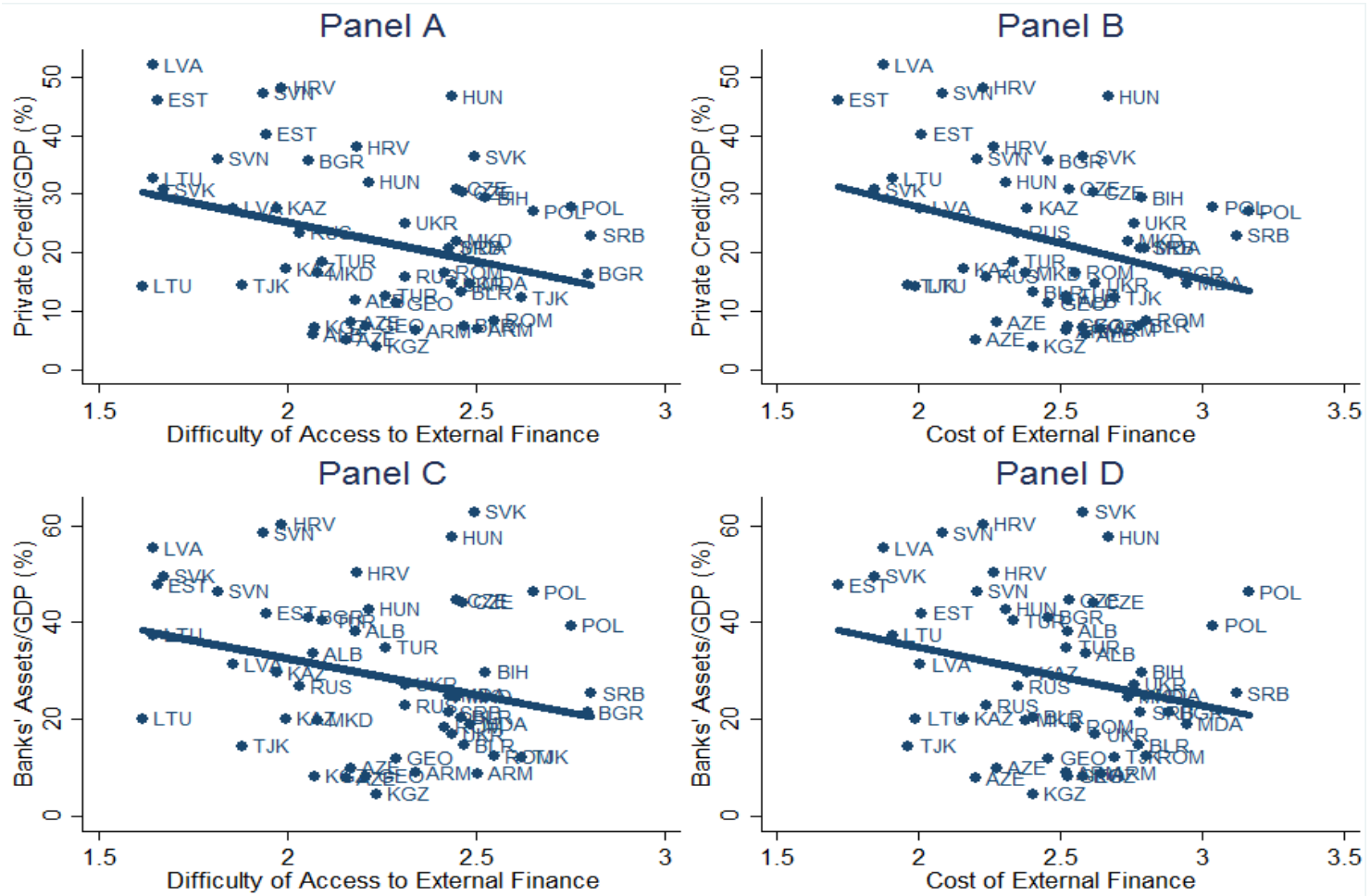

Table A1. Selected Summary Statistics by Country

\begin{tabular}{lccc}
\hline Country & $\begin{array}{c}\text { Percent Reported Sales } \\
(\text { Mean) }\end{array}$ & $\begin{array}{c}\text { Difficulty of Access } \\
\text { to External Finance (Mean) }\end{array}$ & $\begin{array}{c}\text { Cost of External Finance } \\
\text { (Mean) }\end{array}$ \\
\hline Albania & 77.235 & 2.132 & 2.555 \\
& $(22.624)$ & $(1.101)$ & 2.604 \\
Armenia & 94.026 & 2.451 & $(1.089)$ \\
& $(12.730)$ & $(1.069)$ & 2.252 \\
Azerbaijan & 86.317 & 2.163 & $(0.947)$ \\
& $(21.463)$ & $(0.952)$ & 2.563 \\
Belarus & 92.408 & 2.463 & $(1.113)$ \\
& $(17.330)$ & $(1.162)$ & 2.788 \\
Bosnia and Herzegovina & 79.220 & 2.460 & $(1.083)$ \\
& $(29.703)$ & $(1.085)$ & 2.651 \\
Bulgaria & 84.914 & 2.390 & $(1.191)$ \\
Croatia & $(22.019)$ & $(1.220)$ & 2.245
\end{tabular}




\begin{tabular}{|c|c|c|c|}
\hline & $(17.452)$ & $(1.165)$ & (1.049) \\
\hline \multirow[t]{2}{*}{ Czech Republic } & 88.244 & 2.456 & 2.581 \\
\hline & (18.383) & (1.098) & (1.010) \\
\hline \multirow[t]{2}{*}{ Estonia } & 95.042 & 1.780 & 1.847 \\
\hline & (10.530) & (1.014) & $(0.934)$ \\
\hline \multirow[t]{2}{*}{ FYR Macedonia } & 70.500 & 2.282 & 2.570 \\
\hline & (30.393) & (1.137) & $(1.151)$ \\
\hline \multirow[t]{2}{*}{ Georgia } & 76.518 & 2.249 & 2.492 \\
\hline & $(27.542)$ & $(1.130)$ & (1.134) \\
\hline \multirow[t]{2}{*}{ Hungary } & 88.648 & 2.370 & 2.563 \\
\hline & (19.109) & (1.198) & (1.147) \\
\hline \multirow[t]{2}{*}{ Kazakhstan } & 90.458 & 1.979 & 2.320 \\
\hline & (19.718) & $(1.053)$ & (1.079) \\
\hline \multirow[t]{2}{*}{ Kyrgyz Republic } & 80.655 & 2.147 & 2.501 \\
\hline & $(25.721)$ & (1.139) & (1.173) \\
\hline \multirow[t]{2}{*}{ Latvia } & 90.446 & 1.740 & 1.936 \\
\hline & (17.789) & $(0.986)$ & $(0.995)$ \\
\hline \multirow[t]{2}{*}{ Lithuania } & 87.503 & 1.629 & 1.949 \\
\hline & (21.193) & $(0.986)$ & (1.004) \\
\hline \multirow[t]{2}{*}{ Moldova } & 86.061 & 2.449 & 2.850 \\
\hline & (20.506) & (1.111) & (1.164) \\
\hline \multirow[t]{2}{*}{ Poland } & 90.071 & 2.717 & 3.082 \\
\hline & (15.538) & $(1.149)$ & $(1.050)$ \\
\hline \multirow[t]{2}{*}{ Romania } & 91.493 & 2.454 & 2.627 \\
\hline & (16.113) & $(1.140)$ & (1.111) \\
\hline \multirow[t]{2}{*}{ Russia } & 83.382 & 2.157 & 2.300 \\
\hline & (23.949) & $(1.121)$ & $(1.072)$ \\
\hline \multirow[t]{2}{*}{ Serbia } & 82.275 & 2.639 & 2.972 \\
\hline & (26.297) & $(1.152)$ & (1.094) \\
\hline \multirow[t]{2}{*}{ Slovak Republic } & 91.997 & 2.039 & 2.172 \\
\hline & (15.605) & $(1.152)$ & (1.110) \\
\hline \multirow[t]{2}{*}{ Slovenia } & 88.219 & 1.881 & 2.138 \\
\hline & (21.788) & $(1.002)$ & (1.013) \\
\hline \multirow[t]{2}{*}{ Tajikistan } & 82.596 & 2.231 & 2.310 \\
\hline & (25.111) & $(1.037)$ & $(1.072)$ \\
\hline \multirow[t]{2}{*}{ Turkey } & 78.212 & 2.172 & 2.424 \\
\hline & (25.628) & (1.103) & (1.159) \\
\hline \multirow[t]{2}{*}{ Ukraine } & 87.671 & 2.366 & 2.702 \\
\hline & (24.032) & (1.192) & (1.167) \\
\hline \multirow[t]{2}{*}{ Uzbekistan } & 93.619 & 2.191 & 2.219 \\
\hline & (16.678) & $(1.145)$ & $(1.120)$ \\
\hline
\end{tabular}


Table A2. Robustness Checks: Alternative Measures of Tax Evasion

\begin{tabular}{|c|c|c|c|c|c|c|}
\hline \multirow[t]{2}{*}{ Dependent Variable } & \multicolumn{2}{|c|}{$\begin{array}{c}\text { Percent Reported } \\
\text { Workforce }\end{array}$} & \multicolumn{2}{|c|}{$\begin{array}{c}\text { Percent Reported } \\
\text { Wage Bill }\end{array}$} & \multicolumn{2}{|c|}{ Evasion Dummy } \\
\hline & (1) & $(2)$ & (3) & (4) & (5) & (6) \\
\hline \multirow[t]{2}{*}{ Difficulty of Access to External Finance } & $-9.706 * * *$ & & $-10.763 * * *$ & & $0.516^{* * *}$ & \\
\hline & $(3.666)$ & & $(4.148)$ & & $(0.123)$ & \\
\hline \multirow[t]{2}{*}{ Cost of External Finance } & & $-17.329 * *$ & & $-20.245^{* *}$ & & $0.818^{* * *}$ \\
\hline & & $(8.122)$ & & $(8.721)$ & & $(0.208)$ \\
\hline Firm-level Controls & Yes & Yes & Yes & Yes & Yes & Yes \\
\hline Country-level Controls & Yes & Yes & Yes & Yes & Yes & Yes \\
\hline Country FE & Yes & Yes & Yes & Yes & Yes & Yes \\
\hline Industry FE & Yes & Yes & Yes & Yes & Yes & Yes \\
\hline Year FE & Yes & Yes & Yes & Yes & Yes & Yes \\
\hline Observations & 5,723 & 5,759 & 5,706 & 5,741 & 9,074 & 9,142 \\
\hline R-squared & -0.206 & -0.846 & -0.179 & -0.867 & - & - \\
\hline IV F-stat & 26.83 & 14.18 & 25.69 & 14.32 & - & - \\
\hline Hansen J & 4.116 & 2.881 & 3.295 & 3.172 & - & - \\
\hline P-value of Hansen $\mathbf{J}$ & 0.128 & 0.237 & 0.193 & 0.205 & - & - \\
\hline
\end{tabular}

Note: The table reports estimates of coefficients from IV or IV probit regressions of the dependent variables on the difficulty of access to external finance and the cost of external finance. Columns (1) to (4) are estimated by IV regressions. Columns (5) and (6) are estimated by IV probit regressions. Newey's two-step estimator is employed in IV probit regressions since the maximum likelihood estimator may have difficulty converging. Fixed effects for country, industry, and year, as well as all other controls at the firm-level and the country-level, are included in all regressions, as described in specification (1) in the text. Firm-level control variables include $\ln ($ Age ), $\ln ($ Labor), In(Sales), Tax Rates as Obstacle, Tax Administration as Obstacle, Audited, and a set of location dummy variables (Other, over 1,000,000; Other, 250,000-1,000,000; Other, 50,000-250,000; Under 50,000). Country-level control variables include Corporate Income Tax Rate, In(Real GDP per Capita), In(Population), Bank Concentration, and Bank Cost to Income Ratio. Robust standard errors clustered at the country level are reported in parentheses. *,**, and *** denote the significance at the $10 \%, 5 \%$, and $1 \%$ level, respectively. 
Table A3. Robustness Checks: Alternative Specifications

\begin{tabular}{|c|c|c|c|c|c|c|c|c|}
\hline \multirow[t]{4}{*}{ Dependent Variable } & \multicolumn{8}{|c|}{ Percent Reported Sales } \\
\hline & \multicolumn{4}{|c|}{ Difficulty of Access to External Finance } & \multicolumn{4}{|c|}{ Cost of External Finance } \\
\hline & Coefficient & Observations & IV F-stat & $\begin{array}{l}\text { P-value of } \\
\text { Hansen } J\end{array}$ & Coefficient & Observations & IV F-stat & $\begin{array}{l}\text { P-value of } \\
\text { Hansen J }\end{array}$ \\
\hline & (1) & (2) & (3) & (4) & (5) & (6) & (7) & (8) \\
\hline \multicolumn{9}{|l|}{ Interactions of Fixed Effects } \\
\hline Industry X Year & $\begin{array}{c}-7.263 * * * \\
(2.694)\end{array}$ & 9,074 & 13.35 & 0.128 & $\begin{array}{c}-11.685^{* * *} \\
(4.722)\end{array}$ & 9,142 & 24.04 & 0.174 \\
\hline Country X Year & $\begin{array}{c}-5.819^{*} \\
(3.096)\end{array}$ & 9,074 & 12.54 & 0.141 & $\begin{array}{c}-10.192^{* * *} \\
(4.771)\end{array}$ & 9,142 & 25.94 & 0.116 \\
\hline Industry X Year \& Country X Year & $\begin{array}{l}-5.261 * \\
(2.983)\end{array}$ & 9,074 & 12.91 & 0.135 & $\begin{array}{c}-9.394 * * \\
(4.579)\end{array}$ & 9,142 & 24.04 & 0.106 \\
\hline \multicolumn{9}{|l|}{ Control for: } \\
\hline $\ln ($ Establishments $)$ & $\begin{array}{c}-7.643 * * * \\
(2.724)\end{array}$ & 9,068 & 12.87 & 0.152 & $\begin{array}{c}-12.261 * * \\
(4.826)\end{array}$ & 9,136 & 24.28 & 0.211 \\
\hline Export & $\begin{array}{c}-7.623 * * * \\
(2.722)\end{array}$ & 9,056 & 12.55 & 0.131 & $\begin{array}{c}-12.497 * * \\
(4.910)\end{array}$ & 9,123 & 24.41 & 0.206 \\
\hline Competition & $\begin{array}{c}-7.601 * * * \\
(2.741)\end{array}$ & 8,905 & 11.83 & 0.127 & $\begin{array}{c}-12.139 * * \\
(4.909)\end{array}$ & 8,969 & 24.41 & 0.185 \\
\hline Manager's Time Spent with Officials & $\begin{array}{c}-6.762 * * \\
(2.700)\end{array}$ & 8,818 & 11.80 & 0.169 & $\begin{array}{c}-11.394^{* *} \\
(5.081)\end{array}$ & 8,882 & 23.27 & 0.163 \\
\hline Association & $\begin{array}{c}-7.553 * * * \\
(2.705)\end{array}$ & 9,074 & 12.67 & 0.148 & $\begin{array}{c}-12.132 * * \\
(4.813)\end{array}$ & 9,142 & 23.35 & 0.207 \\
\hline Bank Loan Ratio & $\begin{array}{c}-7.445^{* * *} \\
(2.576)\end{array}$ & 8,664 & 11.58 & 0.244 & $\begin{array}{c}-11.381 * * \\
(4.765)\end{array}$ & 8,742 & 25.28 & 0.266 \\
\hline
\end{tabular}




\begin{tabular}{|c|c|c|c|c|c|c|c|c|}
\hline Stock Capitalization Ratio & $\begin{array}{c}-6.070^{* *} \\
(2.728)\end{array}$ & 7,799 & 14.81 & 0.198 & $\begin{array}{c}-13.959 * * \\
(5.683)\end{array}$ & 7,854 & 25.48 & 0.413 \\
\hline Boone Indicator & $\begin{array}{c}-7.551 * * * \\
(2.623)\end{array}$ & 9,074 & 13.55 & 0.175 & $\begin{array}{c}-12.216^{* *} \\
(4.761)\end{array}$ & 9,142 & 24.15 & 0.246 \\
\hline Lerner Index & $\begin{array}{c}-6.996 * * \\
(2.808)\end{array}$ & 8,842 & 12.47 & 0.318 & $\begin{array}{c}-12.905 * * \\
(5.068)\end{array}$ & 8,909 & 21.14 & 0.349 \\
\hline Include All Controls & $\begin{array}{c}-5.883 * * \\
(2.912)\end{array}$ & 7,083 & 11.70 & 0.200 & $\begin{array}{c}-15.752 * * \\
(7.043)\end{array}$ & 7,143 & 19.94 & 0.390 \\
\hline
\end{tabular}


Table A4. Robustness Checks: Extended Sample

\begin{tabular}{|c|c|c|c|c|c|c|}
\hline \multirow[t]{3}{*}{ Dependent Variable } & \multicolumn{6}{|c|}{ Percent Reported Sales } \\
\hline & \multicolumn{4}{|c|}{ Panel A: 2002-2005 } & \multicolumn{2}{|c|}{ Panel B: 2002-2010 } \\
\hline & (1) & (2) & (3) & (4) & (5) & (6) \\
\hline Difficulty of Access to & $-1.120 * * *$ & $-0.449 * *$ & & & $-0.779 * * *$ & $-0.508 * * *$ \\
\hline External Finance & $(0.246)$ & $(0.192)$ & & & $(0.200)$ & $(0.155)$ \\
\hline \multirow[t]{2}{*}{ Cost of External Finance } & & & $-0.820 * * *$ & $-0.286 \dagger$ & & \\
\hline & & & $(0.237)$ & $(0.206)$ & & \\
\hline Firm-level Controls & No & Yes & No & Yes & No & Yes \\
\hline Country-level Controls & No & Yes & No & Yes & No & Yes \\
\hline Country FE & Yes & Yes & Yes & Yes & Yes & Yes \\
\hline Industry FE & Yes & Yes & Yes & Yes & Yes & Yes \\
\hline Year FE & Yes & Yes & Yes & Yes & Yes & Yes \\
\hline Observations & 34,631 & 16,134 & 34,810 & 16,177 & 68,499 & 20,187 \\
\hline Number of Countries & 71 & 46 & 71 & 46 & 102 & 49 \\
\hline R-squared & 0.212 & 0.271 & 0.211 & 0.270 & 0.191 & 0.242 \\
\hline
\end{tabular}

Note: The table reports estimates of coefficients from OLS regressions of the percent reported sales on the difficulty of access to external finance and the cost of external finance. The pooled sample periods are 2002 to 2005 for Panel A and 2002 to 2010 for Panel B. Fixed effects for country, industry, and year are included in all regressions. Firm-level control variables include $\ln ($ Age $), \ln ($ Labor), $\ln ($ Sales), Tax Rates as Obstacle, Tax Administration as Obstacle, Audited, and a set of location dummy variables (Other, over 1,000,000; Other, 250,000-1,000,000; Other, 50,000-250,000; Under 50,000). Country-level control variables include Corporate Income Tax Rate, In(Real GDP per Capita), In(Population), Bank Concentration, and Bank Cost to Income Ratio. Robust standard errors clustered at the country level are reported in parentheses. *,**, and *** denote the significance at the $10 \%, 5 \%$, and $1 \%$ level, respectively. ${ }^{\dagger}$ denotes the significance at the $10 \%$ level under a one-tail test. 